\title{
Engineering Considerations to Produce Bioactive Compounds from Plant Cell Suspension Culture in Bioreactors
}

\author{
Elizabeth Alejandra Motolinía-Alcántara ${ }^{1}$, Carlos Omar Castillo-Araiza ${ }^{2}{ }^{\oplus}$, Mario Rodríguez-Monroy ${ }^{3}$, \\ Angélica Román-Guerrero ${ }^{1, *(\mathbb{D})}$ and Francisco Cruz-Sosa ${ }^{1, *(\mathbb{D})}$ \\ 1 Departamento de Biotecnología, Universidad Autónoma Metropolitana-Iztapalapa, \\ Av. Ferrocarril de San Rafael Atlixco 186, Ciudad de México 09310, Mexico; eama@xanum.uam.mx \\ 2 Departamento de Ingeniería de Procesos e Hidráulica, Universidad Autónoma Metropolitana-Iztapalapa, \\ Av. Ferrocarril de San Rafael Atlixco 186, Ciudad de México 09310, Mexico; coca@xanum.uam.mx \\ 3 Centro de Desarrollo de Productos Bióticos (CEPROBI), Departamento de Biotecnología, \\ Instituto Politécnico Nacional (IPN), Yautepec 62731, Mexico; mrmonroy@ipn.mx \\ * Correspondence: arogue@xanum.uam.mx (A.R.-G.); cuhp@xanum.uam.mx (F.C.-S.); \\ Tel.: +52-55-5804-4600 (ext. 2847) (A.R.-G.)
}

\section{check for} updates

Citation: Motolinía-Alcántara, E.A.; Castillo-Araiza, C.O.; RodríguezMonroy, M.; Román-Guerrero, A.; Cruz-Sosa, F. Engineering

Considerations to Produce Bioactive Compounds from Plant Cell Suspension Culture in Bioreactors. Plants 2021, 10, 2762. https:// doi.org/10.3390/plants10122762

Academic Editors: Milan S. Stankovic, Paula Baptista and Petronia Carillo

Received: 9 November 2021

Accepted: 6 December 2021

Published: 14 December 2021

Publisher's Note: MDPI stays neutral with regard to jurisdictional claims in published maps and institutional affiliations.

Copyright: (c) 2021 by the authors. Licensee MDPI, Basel, Switzerland. This article is an open access article distributed under the terms and conditions of the Creative Commons Attribution (CC BY) license (https:// creativecommons.org/licenses/by/ $4.0 /)$.

\begin{abstract}
The large-scale production of plant-derived secondary metabolites (PDSM) in bioreactors to meet the increasing demand for bioactive compounds for the treatment and prevention of degenerative diseases is nowadays considered an engineering challenge due to the large number of operational factors that need to be considered during their design and scale-up. The plant cell suspension culture (CSC) has presented numerous benefits over other technologies, such as the conventional whole-plant extraction, not only for avoiding the overexploitation of plant species, but also for achieving better yields and having excellent scaling-up attributes. The selection of the bioreactor configuration depends on intrinsic cell culture properties and engineering considerations related to the effect of operating conditions on thermodynamics, kinetics, and transport phenomena, which together are essential for accomplishing the large-scale production of PDSM. To this end, this review, firstly, provides a comprehensive appraisement of PDSM, essentially those with demonstrated importance and utilization in pharmaceutical industries. Then, special attention is given to PDSM obtained out of CSC. Finally, engineering aspects related to the bioreactor configuration for CSC stating the effect of the operating conditions on kinetics and transport phenomena and, hence, on the cell viability and production of PDSM are presented accordingly. The engineering analysis of the reviewed bioreactor configurations for CSC will pave the way for future research focused on their scaling up, to produce high value-added PDSM.
\end{abstract}

Keywords: medicinal plant; bioactive compounds; plant-derived secondary metabolites (PDSM); cell suspension culture (CSC); bioreactor engineering

\section{Introduction}

The plant world has been exploited for thousands of years by human cultures for preventing pain, producing pleasure, usage in religious ceremonies, and treating different diseases and illnesses. Recently, the World Health Organization (WHO) estimated that 80 percent of people worldwide rely on herbal medicines for some aspect of their primary healthcare importance. Medicinal plants have great significance in the health industry. Today, almost $25 \%$ of modern medicines are obtained or derived from natural sources [1-3]. To this end, according to a recent report by the British Broadcasting Corporation (BBC), plant-derived drugs will grow from USD 29.3 billion in 2017 to around USD 39.2 billion by 2022 , with a compound annual growth rate (CAGR) of $6.1 \%$ per year for the same period.

The chemical entities responsible for the biological activity in medicinal plants are organic molecules classified as secondary metabolites. Although there are more than 50,000 plant species used for medicinal purposes, bioactive compounds in plant tissues 
generally account for less than $1 \%$ (wt.), leading to the overexploitation, threatening, or extinction of vegetal species [4-6]. In agreement with Süntar et al. [7], half of the drugs used for clinical treatments are obtained out of natural sources, accounting for 185 chemical compounds approved by the FDA [8]. Due to the growing interest in obtaining phytochemicals from plant-derived secondary metabolites (PDSM), the use of biotechnologies based on the plant cell culture (PCC) results in a promising, sustainable, and environmentally friendly way of overcoming the problems related to either the traditional cultivation of medicinal plants (including variations in crop quality associated with drought or flood crops, diseases or pest attacks on plants, or the chemical synthesis of bioactive compounds, allowing a better control in the quality and higher yields of the desired products to be achieved.

Academia and industry, nowadays, aim their research on PCC for large-scale production of bioactive compounds by using callus cells, immobilized cells, embryos, roots, shoots, and suspended cells $[9,10]$. Among PCC, the plant cell suspension culture (CSC) is one of the processes that presents excellent scaling-up attributes for producing plant-derived secondary metabolites (PDSM). Nevertheless, although the use of CSC seems an attractive bioreaction concept for large-scale production of bioactive compounds [11-13], there is a lack of information related to the engineering of the bioreactor technology because of the complex interaction between the operational variables and its performance regarding microbiology, thermodynamics, kinetics, and transport phenomena, which, in turn, impact on the production and quality of PDSM.

This review, in its first part, states the main bioactive compounds found in plants with great commercial relevance, giving an overview of the types of compounds and their different biological activities, and stressing the relevance of PCC for satisfying the today's demand for bioactive compounds. The second part is focused on the production of bioactive compounds by CSC, summarizing the engineering strategies followed in the literature for achieving large-scale production and indicating the characteristics required from plant tissues to obtain CSC with adequate properties. Bioreactor configurations implemented for CSC are also described in this section. Because of its impact on the design and scale-up of CSC, the third part elucidates the impact of the bioreactor configuration and operational conditions on the performance of plant cell cultures during the production of PDSM.

\section{Bioactive Compounds in Plants}

Medicinal plants are considered as a resource for bioactive compounds that can be used for obtaining pharmacopeial or non-pharmacopeial drugs, contributing to the rising interest and demand for plant-derived phytochemicals [14-16]. Their main activities include antioxidant, anti-inflammatory, antiproliferative, anticancer, anti-neurodegenerative disorders, and chronic diseases, among other health properties [17]. These bioactive compounds are considered as plant-derived secondary metabolites (PDSM) since, in contrast to the primary metabolites, they do not play an active role in the direct metabolic process or growth of the plant, but their importance relies on their interactions with biotic and abiotic stresses in defense of the plant viability $[7,18,19]$.

PDSM are classified in three main groups: (i) terpenes and terpenoid compounds formed by 5-C isopentanoid units, (ii) phenolic compounds derived from the shikimic acid pathway, and (iii) nitrogen and sulfur comprising compounds (Figure 1) synthesized from common amino acids [18]. Their classification is based on their composition, structure, the pathway used for their biosynthesis, and their chemical nature (solubility, polarity, reactivity) [17,20-22]. PSDM are normally produced out of specific plant species or taxonomy [18]. Table 1 describes the main characteristics and biological activities reported for the three groups of PDSM.

PDSM are, in general, extracted from roots and aerial parts of the plant, with typical yields below $1 \% \mathrm{wt}$. Their production usually takes very long cultivation times for reaching the plant maturity and ensuring the highest PDSM production, thus requiring large amounts of plant material for satisfying the demand of bioactive compounds in the food 
and pharmaceutical industries, and leading to the overexploitation and extinction of the vegetal species, despite the risk of unpredictable differences in the homogeneity and quality of the extracted vegetal due to environmental factors during cultivation $[16,18,23,24]$. Therefore, it is important to implement novel technologies that allow the production of bioactive compounds in more sustainable and better controlled processes. Among the biotechnological strategies proposed in the literature to produce PDSM out of PCC, the root culture, shoot culture, hairy root culture, and cell suspension culture are some of the most studied in the laboratory scale.
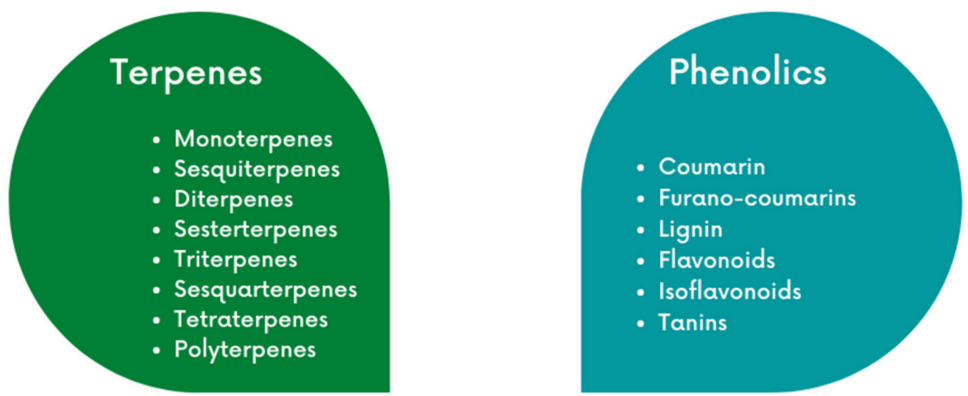

\section{SECONDARY METABOLITES IN PLANTS}

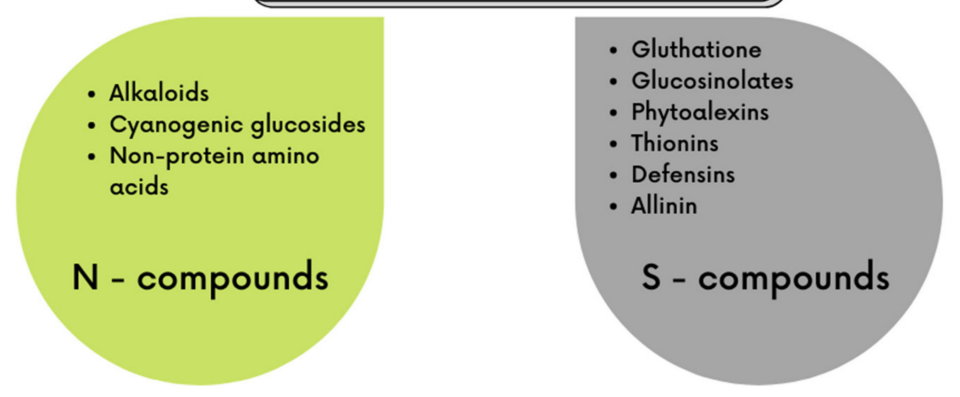

Figure 1. Classification and types of PDSM.

Table 1. Characteristics and biological activities reported for PDSM in medicinal plants.

\begin{tabular}{|c|c|c|c|c|}
\hline Compound & Characteristics & Representative Compounds & $\begin{array}{c}\text { Biological/ } \\
\text { Pharmacological Properties }\end{array}$ & References \\
\hline Alkaloids & $\begin{array}{l}\text { Complex organic molecules with a } \\
\text { heterocyclic nitrogen ring. } \\
\uparrow 10,000 \text { compounds isolated } \\
\uparrow 300 \text { families of plants }\end{array}$ & $\begin{array}{l}\text { Piperine; nicotine, vasicine; theobromine; } \\
\text { caffeine; aconitine; atropine; quinine; } \\
\text { capsaicin, ephedrine; paclitaxel; } \\
\text { morphine; berberine; vincristine; }\end{array}$ & $\begin{array}{c}\text { Chemotherapeutic agents; } \\
\text { antiproliferative; antimicrobial and } \\
\text { antiparasitic activities; analgesic, } \\
\text { anti-hyperglycemic, Alzheimer's and } \\
\text { Parkinson's diseases, stroke, } \\
\text { epilepsy, fungicide. }\end{array}$ & [25-29] \\
\hline $\begin{array}{l}\text { Phenolic } \\
\text { compounds }\end{array}$ & $\begin{array}{c}\text { They are diverse in structure, and } \\
\text { present in common } \\
\text { the hydroxylated aromatic rings. } \\
\uparrow 8000 \text { different } \\
\text { compounds identified } \\
\uparrow 300 \text { families of plants }\end{array}$ & $\begin{array}{c}\text { Simple phenolics: } \\
\text { hydroquinone, pyrogallol acid. } \\
\text { Single phenolic ring: } \\
\text { gallic acid, salicylic acid, caffeic acid, } \\
\text { hydroxycinnamic acids. } \\
\text { Two phenolic rings: } \\
\text { Xanthones, stilbenes, flavonoids. } \\
\text { Quinines: } \\
\text { Benzoquinones, naphtaquinones } \\
\text { anthraquinones, tannins and lignans. }\end{array}$ & $\begin{array}{c}\text { Antioxidant, anti-inflammatory, } \\
\text { anticarcinogenic, cardiovascular } \\
\text { protective effect, antidiabetic, anti-obesity, } \\
\text { antihemolytic, antibacterial, liver } \\
\text { protection, antiatherogenic, } \\
\text { antiviral, neuroprotective functions. }\end{array}$ & [30-35] \\
\hline Terpenes & $\begin{array}{l}\text { Synthesized from acetate via the } \\
\text { mevalonic acid pathway. } \\
\text { They comprise natural } \\
\text { hydrocarbons with } \\
\text { isoprene blocks. } \\
\uparrow 23,000 \text { compounds identified. }\end{array}$ & $\begin{array}{c}\text { Monoterpenes: menthol. } \\
\text { Sesquiterpenes: zingiberene. } \\
\text { Diterpenes: retinol. } \\
\text { Triterpenes: squalene. } \\
\text { Tetraterpene: } \beta \text {-carotene. }\end{array}$ & $\begin{array}{l}\text { Anti-hypertensive activity, antimicrobial, } \\
\text { insecticide, fungicide, antioxidant, } \\
\text { anticonvulsant, anti-tumor and } \\
\text { neurotrophic effects, immune function, } \\
\text { skin protection, UV protection, anticancer, } \\
\text { antiparasitic, antihyperglycemic. }\end{array}$ & {$[28-30,36,37]$} \\
\hline $\begin{array}{l}\text { Sulfur-rich } \\
\text { compounds } \\
\text { (SRGs) }\end{array}$ & $\begin{array}{l}\text { The structure is composed of a } \\
\beta \text {-D-glucosyl residue linked by a } \\
\text { sulfur atom. } \\
\text { About } 137 \text { SRGs identified } \\
\text { in plants }\end{array}$ & $\begin{array}{l}\text { Glutathione, glucosinolates, } \\
\text { phytoalexines, thionines, }\end{array}$ & $\begin{array}{l}\text { Enzyme regulator, intercellular signaling } \\
\text { molecule, antitumor effect, Burkitt } \\
\text { lymphoma treatment, anticancer. }\end{array}$ & [38-41] \\
\hline
\end{tabular}




\section{Plant Cell Culture}

Plant cell culture (PCC) is nowadays recognized as a promising, renewable, sustainable, and environmentally friendly alternative to obtain PDSM out of wild plants. PCC accounts for the virtues of whole-plant cultivation systems and offers significant advantages, such as controlled manufacture due to standardized environmental conditions, i.e., it is not seasonal dependent, makes use of low amounts of water, and pesticides and herbicides are not required, achieving better quality in the desired product $[42,43]$. The establishment of different types of plant cell cultures are aimed for regenerating organs or somatic embryos for plant propagation, virus elimination, genetic manipulation, germplasm storage, and for in vitro production of PDSM [44,45]. The main differences found in the literature about in vitro plant cell cultures with whole wild plants comprise a higher cell growth intensity, the mechanisms of synthesis and reserve organelles for PDSM, and the concentration of PDSM. Despite most of the PDSM contents recovered in plant cell cultures usually being lower than those obtained in wild plants, there are some successful cases where super-producer strains have been achieved [46,47]. According to the literature [48], PCC is defined as the process where plant cells or plant tissues are isolated from plant organs and cultivated under artificial environmental conditions, taking advantage of plants' regeneration ability by means of cuttings or explants. Thus, the resultant proliferated plant cells maintain the genetic information from the donor plant. In the literature [49], it has been elucidated how PCC works as a technological platform where chromosome doubling and artificial polyploidy induction are favored by getting the overexpression of key genes involved in the synthesis of PDSM and, hence, favoring the production of both high-value bioactive compounds and plants with more agronomical potency. Plant cell cultures include the production of callus and immobilized cells, embryos, roots, shoots, and cell suspensions, extending the advantages of manipulation with a better understanding about the intricate mechanisms of synthesis of PDSM [44].

\subsection{Types of Cell Cultures}

Calluses relate to the massive growth of cells and the buildup of agglomerated dedifferentiated cells, that may be able to revamp the complete plant, acquiring features like meristematic cells and developing new stem cells, which are able to form new individual plants [50]. Somatic embryos are obtained by the tissue formation from somatic cells or callus, having as the main objective the micropropagation of species seeds. Hairy roots culture is usually obtained by the infection of plant cells with Agrobacterium rhizogenes, resulting in the transformation of callus into differentiated tissues [48].

Even though there are several studies where the production of PDSM from callus cultures and differentiated cells/tissues are used, the cell suspension culture from dedifferentiated cells is mostly preferred [51,52]. Cell suspension cell culture (CSC) is considered as a simple and cost-effective method, allowing suitable conditions for cells to produce compounds identical to those from parental cells to be achieved, offering advantages such as setting stable systems for continuous PDSM production with homogeneity in yields and quality, as well as offering the possibility of synthesizing new compounds and greater potential for PDSM commercial application [51,53]. Therefore, CSC has been demonstrated to be the selected biotechnological tool for obtaining high-value PDSM, such as taxol [53,54], resveratrol [55,56], and ginsenosides [57], among others. To this end, further discussions will be centered on CSC for producing PDSM at laboratory and larger scales using different bioreactor configurations. Table 2 shows recent successful examples where plant cell culture is used for producing PDSM with pharmacological relevance. 
Table 2. PDSM from medicinal plants successfully produced in the in vitro plant cell culture, bioactivities, and yield comparison.

\begin{tabular}{|c|c|c|c|c|c|c|}
\hline \multirow{2}{*}{ Compound } & \multirow{2}{*}{ Plant Species } & \multirow{2}{*}{$\begin{array}{l}\text { Biological Activity/ } \\
\text { Pharmaceutical Use }\end{array}$} & \multicolumn{2}{|c|}{ Extraction Yield } & \multirow{2}{*}{ Type of Culture } & \multirow{2}{*}{ Ref. } \\
\hline & & & Mother Plant & In Vitro Cell Culture & & \\
\hline Shikonin & $\begin{array}{l}\text { Lithospermum erythrorhizon } \\
\text { Alkanna tinctoria Tausch } \\
\text { Echium plantagineum L. }\end{array}$ & $\begin{array}{l}\text { Anticancer, antibacterial, anti-inflammatory, hepatic } \\
\text { steatosis attenuator, antitumor, and antioxidants }\end{array}$ & $10-20 \mathrm{mg} / \mathrm{g}$ & $\begin{array}{l}150-200 \mathrm{mg} / \mathrm{g} \\
36.25 \mathrm{mg} / \mathrm{L}\end{array}$ & $\begin{array}{l}\text { CSC } \\
\text { HRC }\end{array}$ & $\begin{array}{c}{[58-62]} \\
{[63]}\end{array}$ \\
\hline Anthraquinones & $\begin{array}{l}\text { Morinda citrifolia } \\
\text { Rubia cordifolia } \\
\text { Senna obtusifolia }\end{array}$ & $\begin{array}{l}\text { Antimicrobial, antifungal, hypotensive, analgesic, } \\
\text { antimalarial, gastroprotective, antioxidant, hepatoprotective } \\
\text { and antileukemic, and mutagenic functions }\end{array}$ & $3 \mathrm{mg} / \mathrm{g}$ & $100-200 \mathrm{mg} / \mathrm{g}$ & $\begin{array}{l}\text { HRC } \\
\text { CCC } \\
\text { CSC }\end{array}$ & [64-67] \\
\hline Rosmarinic acid & $\begin{array}{l}\text { Ocimum basilicum } \\
\text { Origanum vulgare } \\
\text { Satureja khuzistanica } \\
\text { Coleus blumei } \\
\text { Salvia officinalis }\end{array}$ & Antioxidant, anti-inflammatory, antiviral activities & $\begin{array}{c}8.78-9.4 \mathrm{mg} / \mathrm{g} \\
23.53 \mathrm{mg} / \mathrm{g} \\
12 \mathrm{mg} / \mathrm{g} \\
30 \mathrm{mg} / \mathrm{g} \\
30 \mathrm{mg} / \mathrm{g}\end{array}$ & $\begin{array}{c}12.32-21.28 \mathrm{mg} / \mathrm{g} \\
31.25 \mathrm{mg} / \mathrm{g} \\
38 \mathrm{mg} / \mathrm{g} \\
270 \mathrm{mg} / \mathrm{g} \\
360 \mathrm{mg} / \mathrm{g}\end{array}$ & $\begin{array}{l}\text { CSC } \\
\text { CSC } \\
\text { CSC } \\
\text { CSC } \\
\text { CSC }\end{array}$ & $\begin{array}{c}68,69] \\
{[70,71]} \\
{[72,73]} \\
{[32]}\end{array}$ \\
\hline Berberine & $\begin{array}{l}\text { Thalictrum minus } \\
\text { Coptis japonica } \\
\text { Coscinium fenestratum }\end{array}$ & $\begin{array}{l}\text { Effects antitumor, anticancer, lower blood lipid, lower blood } \\
\text { glucose, anti-osteoporosis, anti-osteoarthritis, antibiotic, and } \\
\text { anti-inflammatory }\end{array}$ & $\begin{array}{c}0.1 \mathrm{mg} / \mathrm{g} \\
20-40 \mathrm{mg} / \mathrm{g} \\
1 \mathrm{mg} / \mathrm{g}\end{array}$ & $\begin{array}{l}0.8 \mathrm{mg} / \mathrm{mL} \\
132 \mathrm{mg} / \mathrm{g} \\
178 \mathrm{mg} / \mathrm{g}\end{array}$ & $\begin{array}{l}\text { CSC } \\
\text { CSC } \\
\text { CCC }\end{array}$ & [74-79] \\
\hline Ginsenosides & $\begin{array}{c}\text { Panax ginseng } \\
\text { Panax japonicus } \\
\text { Panax notoginseng }\end{array}$ & $\begin{array}{l}\text { Antitumor, immunological, anti-inflammation, anticancer, } \\
\text { antidiabetic, and cardiovascular-protective }\end{array}$ & $0.015-8 \mathrm{mg} / \mathrm{g}$ & $\begin{array}{c}36.4-80 \mathrm{mg} / \mathrm{g} \\
3.4-28.9 \mathrm{mg} / \mathrm{g} \\
15.105 .6 \mathrm{mg} / \mathrm{g} \\
20-50 \mathrm{mg} / \mathrm{g} \\
60 \mathrm{mg} / \mathrm{g} \\
71.94 \mathrm{mg} / \mathrm{g} \\
40 \mathrm{mg} / \mathrm{g}\end{array}$ & $\begin{array}{l}\text { HRC } \\
\text { CSC } \\
\text { ARC } \\
\text { CSC } \\
\text { CCC } \\
\text { ARC } \\
\text { CSC }\end{array}$ & {$[57,80,81]$} \\
\hline Ajmalicine & Catharanthus roseus & Antihypertensive, obstructive circulatory diseases treatment & $3 \mathrm{mg} / \mathrm{g}$ & $\begin{array}{l}63 \mathrm{mg} / \mathrm{L} \\
10 \mathrm{mg} / \mathrm{g} \\
34 \mathrm{mg} / \mathrm{L}\end{array}$ & $\begin{array}{l}\text { CCC } \\
\text { CSC } \\
\text { HRC }\end{array}$ & $\begin{array}{c}{[85]} \\
{[86,87]}\end{array}$ \\
\hline Paclitaxel & Taxus chinensis & Anticancer & $0.02 \mathrm{mg} / \mathrm{g}$ & $1.5 \mathrm{mg} / \mathrm{g}$ & CSC & [88] \\
\hline Podophyllotoxin & $\begin{array}{l}\text { Linum narbonense } \\
\text { Juniperus chinensi } \\
\text { Linum flavum }\end{array}$ & Vigorous antimitotic and antiviral activities and anticancer & $\begin{array}{l}0.5 \mathrm{mg} / \mathrm{g} \\
0.025 \mathrm{mg} / \mathrm{g} \\
1.6 \mathrm{mg} / \mathrm{g}\end{array}$ & $\begin{array}{l}1.57 \mathrm{mg} / \mathrm{g} \\
189.91 \mathrm{mg} / \mathrm{g} \\
2 \mathrm{mg} / \mathrm{g}\end{array}$ & $\begin{array}{l}\text { CCC } \\
\text { CSC } \\
\text { CSC }\end{array}$ & [89] \\
\hline Artemisinin & Artemisia annua $\mathrm{L}$. & Treat multi-drug-resistant strains of falciparum malaria & $1-15 \mathrm{mg} / \mathrm{g}$ & $9.33-110.2 \mathrm{mg} / \mathrm{L}$ & CSC & {$[90,91]$} \\
\hline $\begin{array}{l}\text { Phenolic Acids } \\
\text { (rosmarinic, chlorogenic, and } \\
\text { ferulic acid) }\end{array}$ & Verbena officinalis & Antimicrobial, secretolytic, expectorant, and diuretic agent & $136.59 \mathrm{mg} / \mathrm{g}$ & $\begin{array}{l}126.55 \mathrm{mg} / \mathrm{g} \\
189.91 \mathrm{mg} / \mathrm{g}\end{array}$ & $\begin{array}{l}\mathrm{CCC} \\
\mathrm{CSC}\end{array}$ & [92] \\
\hline Resveratrol & Vitis vinifera $\mathrm{L}$. & $\begin{array}{l}\text { Reduced coronary heart disease mortality rates and } \\
\text { atherosclerosis, inhibiting low-density lipoprotein oxidation, } \\
\text { and carcinogenesis }\end{array}$ & NR & $277.89 \mu \mathrm{g} / \mathrm{g}$ & CSC & [7] \\
\hline
\end{tabular}

CSC means cell suspension culture; HRC means hairy root culture; CCC means callus cell culture, ARC adventitious root culture; NR means not reported. 


\subsection{Plant Cell Suspension Culture}

Plant cell suspension culture (CSC) represents a cost-effective and simple biological process for the synthesis of PDSM at large scales [51]. This production concept takes advantage of plant cells as biosynthetically totipotent structures, being capable of obtaining bioactive compounds with identical properties to those contained in plant stem cells, offering potential advantages regarding quality and yield of PDSM [51,93]. To this end, although there are engineering challenges, CSC offers greater potential for industrial applications in large-scale bioreactors than plant tissue and organ cultures. Although the latter ones offer better genetic stability in propagated cells, the design of the bioreactors for their maintenance usually requires greater investments and careful experimentation in the preliminary scale-up stage $[42,94]$.

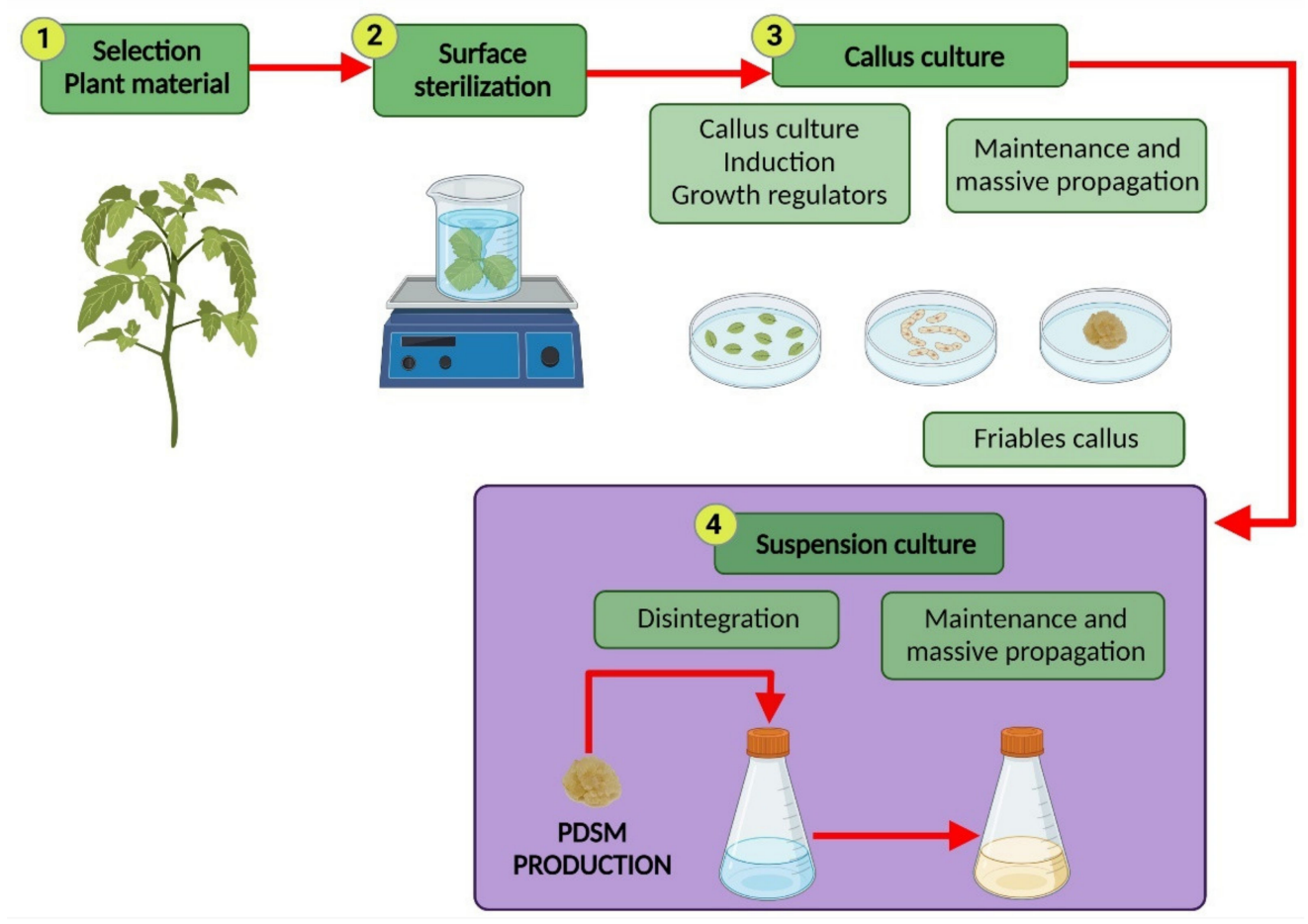

Figure 2. General steps for obtaining cell suspension culture. PDSM means plant-derived secondary metabolites. * Schemes were created with BioRender.com.

Success in the operation of suspension cultures depends on the induction and obtention of friable callus (stage 3) through the exposure to growth regulators, such as auxins and cytokinin. The final step (stage 4) comprises the transfer and maintenance of this cell culture in a liquid. CSC may become unstable when subjected to prolonged culture times, causing differences in the quality and quantity of PDSM; this behavior is due to the consumption and reduced availability of nutrients in the culture media, in addition to genetic variations that can restrict the conservation of the high-yield cell line [9]. Among the strategies used for improving the production of PDSM in CSC is the modification in the culture media composition (different carbon, nitrogen, and phosphorous sources) for optimizing the nutrient availability during the culture time [6,9], and the use of biotic or abiotic elicitors that trigger the defense response from plant cells promoting the secondary metabolism through the introduction of chemical or physical stresses [7,51,95]. Biotic elicitors are complex compounds derived from biological sources, including plant-derived polysaccharides, such as pectin and cellulose, and microbial-derived polysaccharides, such as chitin and glucan [6,44], and plant immune-signaling molecules, such as jasmonic acid [96], salicylic acid [97,98], and methyl jasmonate [96]. Abiotic elicitors include inorganic salts, heavy metals, UV irradiation, high salinity, and pressure [99]. 


\subsection{Commercial Production of PDSM from CSC}

The current production of various drugs, cosmetics, and food ingredients is obtained using plant cell cultures, especially in the form of CSC, as these offer several advantages over other technologies, such as better control during the production of PDSM, a larger feasibility for the scaling up of the process, and shorter production cycles, being environmentally responsible and sustainable processes. The application of CSC to obtain commercial products dates back to the 1960s $[7,9,24,100]$. Table 3 shows a selection of plant cell extracts that have been successfully manufactured at a commercial scale for pharmaceutical purposes. So, by way of history, the first report about industrial manufacturing of bioactive compounds derived from CSC was found for Shikonin from L. erythrorhizon by Mitsui Petrochemical Ind., now Mitsui Chemicals, Inc. (Tokyo, Japan). To date, Taxol ${ }^{\circledR}$, manufactured by Phyton Biotech, Inc. (Delta, BC, Canada), and Genexol, the commercial name for paclitaxel compound by Samyang Genex, represent the cancer drugs with greater demand in the market, with annual sales reaching up to 200-300 kg per year [101]. In agreement with the information available at the website for manufacturers, the production volume for PDSM increases from a few cubic meters to $75 \mathrm{~m}^{3}$ equivalent, to reach $880 \mathrm{~m}^{3}$ per year [102].

Table 3. Plant-derived products manufactured from plant CSC which have entered into the pharmaceutical industry. The list of products makes no claim to be complete.

\begin{tabular}{|c|c|c|c|c|c|}
\hline Product & Species & Pharmaceutical Use & $\begin{array}{l}\text { Manufacturer, Tradename, and } \\
\text { Scale of Production }\end{array}$ & $\begin{array}{l}\text { Type of } \\
\text { Culture }\end{array}$ & Reference \\
\hline Rosmarinic acid & Coleus blumei & Anti-inflammatory & $\begin{array}{l}\text { ANattermann \& Cie. Gmbh, } \\
\text { www.sanofi.de (accessed on } 30 \text { October 2021) }\end{array}$ & CSC & [103] \\
\hline $\begin{array}{c}\text { Echinacea } \\
\text { polysaccharides }\end{array}$ & $\begin{array}{l}\text { Echinacea } \\
\text { purpurea }\end{array}$ & $\begin{array}{l}\text { Immunostimulant, } \\
\text { anti-inflammatory }\end{array}$ & Diversa, 75,000 L bioreactor & CSC & {$[100,104]$} \\
\hline Berberines & $\begin{array}{l}\text { Thalictrum } \\
\text { minun } \\
\text { Coptis japonica }\end{array}$ & $\begin{array}{l}\text { Anticancer; antibiotic; } \\
\text { anti-inflammatory }\end{array}$ & $\begin{array}{l}\text { Mitsui Chemicals, Inc., (75,000 Lbr) } \\
\text { https:/ / www.mitsuichemicals.com/ (accessed on } \\
30 \text { October 2021) }\end{array}$ & $\begin{array}{l}\text { CSC } \\
\text { CSC }\end{array}$ & [105] \\
\hline Podophyllotoxin & $\begin{array}{l}\text { Podophyllum } \\
\text { spp. }\end{array}$ & Anticancer & $\begin{array}{l}\text { Nippon Oil Company, Ltd. } \\
\text { https:/ / www.freepatentsonline.com/5336605.html } \\
\text { (accessed on 30 October 2021) }\end{array}$ & $\begin{array}{l}\text { CSC } \\
\text { OC }\end{array}$ & $\begin{array}{l}{[106]} \\
{[107]}\end{array}$ \\
\hline Docetaxel & Taxus baccata & $\begin{array}{l}\text { Ovarian cancer } \\
\text { treatment }\end{array}$ & $\begin{array}{l}\text { Phyton Biotech, Inc., Taxotere (150 kg/year) } \\
\text { https:/ / phytonbiotech.com/ (accessed on } \\
30 \text { October 2021) }\end{array}$ & CSC & {$[108,109]$} \\
\hline Paclitaxel & Taxus spp. & $\begin{array}{l}\text { Anticancer: FDA } \\
\text { approved for the } \\
\text { treatment of ovarian, } \\
\text { breast, and lung } \\
\text { cancers }\end{array}$ & $\begin{array}{c}\text { Phyton Biotech, Inc., Taxol }{ }^{\circledR}(1000 \mathrm{~kg} / \text { year }) \\
\text { https: / / phytonbiotech.com/ (accessed on } \\
30 \text { October 2021) } \\
\text { Samyang Genex Corporation., Genexol (32,000 Lbr) } \\
\text { https: / / samyangbiopharm.com/eng/ } \\
\text { ProductIntroduce/injection01 (accessed on } \\
\text { 30 October 2021) }\end{array}$ & CSC & $\begin{array}{l}{[110]} \\
{[111]} \\
{[112]}\end{array}$ \\
\hline Scopolamine & Duboisia spp. & $\begin{array}{l}\text { Anticholinergic; } \\
\text { antimuscarinic; } \\
\text { motion sickness, } \\
\text { nausea, and } \\
\text { intestinal cramping }\end{array}$ & $\begin{array}{l}\text { Sumitomo Chemical Co., Ltd., Tokyo, Japan } \\
\quad(50-20,000 \text { Lbr) } \\
\text { https: / / www.sumitomo-chem.co.jp/pharma-chem/ } \\
\text { (accessed on 30 October 2021) }\end{array}$ & HRC & {$[113,114]$} \\
\hline Shikonin & $\begin{array}{l}\text { Lithospermum } \\
\text { erythrorhizon }\end{array}$ & $\begin{array}{l}\text { Anti-HIV, antitumor, } \\
\text { anti-inflammatory }\end{array}$ & $\begin{array}{c}\text { Xi'an NEO Biotech, Shikonin } 95 \% \\
\text { http:/ / www.extractneo.com/about (accessed on } \\
30 \text { October 2021) }\end{array}$ & CSC & {$[100]$} \\
\hline
\end{tabular}

CSC: cell suspension culture; HRC: hairy root culture; OC: organ culture.

\subsection{Typical Bioreactor Configurations}

Bioreactors are defined as containers used to provide a controlled environment to transfer nutrients and oxygen to cell cultures in adequate concentrations that allow the cell to maintain its primary and secondary metabolic activity. Because plant cells, as well as other micro-organisms, are more sensitive and less stable than chemical compounds, biore- 
actor designs must be robust enough to provide a greater degree of control over process disturbances and contamination and achieve high productivities, high quality products, and cost effectiveness. The bioreactor design and its optimal operation depend on the determination of the operating conditions giving rise to the required product formation, minimizing the cost of the process [115]. The most common bioreactor configurations utilized for commercial and large-scale production consist in stirred tank bioreactor (STB), wave stirred bioreactor (WSB), air-lift bioreactor (ALB), and bubble column (BC). The selection of the bioreactor configuration is frequently established by its optimal performance in terms of metabolic activity and kinetics of cell cultures, economic costs, and its flexible operation regarding maintenance of cultures by controlling operational conditions, such as temperature, $\mathrm{pH}$, aseptic, mixing, aeration, and scalability. Table 4 shows some characteristics, advantages, and disadvantages of these types of bioreactors.

Table 4. Comparison of bioreactor configurations commonly used for plant cell culture.

\begin{tabular}{|c|c|c|c|c|c|}
\hline $\begin{array}{c}\text { Bioreactor } \\
\text { Configuration }\end{array}$ & $\begin{array}{l}\text { Schematic } \\
\text { Diagram * }\end{array}$ & Description & Advantages & Disadvantages & Ref. \\
\hline $\begin{array}{c}\text { Bubble } \\
\text { column (BC) }\end{array}$ & Gas inlet & $\begin{array}{l}\text { It is classified in the } \\
\text { pneumatic-type bioreactor. } \\
\text { They are constructed in } \\
\text { cylindric columns where gas } \\
\text { injection represents the only } \\
\text { energy entrance to the } \\
\text { system. BC bioreactors } \\
\text { operate under constant } \\
\text { bubbling where gas flows } \\
\text { from the bottom to the top } \\
\text { through nozzles, perforated } \\
\text { plates, or spray rings, } \\
\text { allowing not only the } \\
\text { aeration process, but also } \\
\text { helping the mixing and } \\
\text { circulation of the fluid, } \\
\text { without the need to install } \\
\text { mechanical accessories. }\end{array}$ & $\begin{array}{l}\text { Simple structure } \\
\text { as no mechanical } \\
\text { force is required } \\
\text { to shake. } \\
\text { Easier } \\
\text { maintenance and } \\
\text { reduces the risk } \\
\text { of contamination } \\
\text { due to the lack of } \\
\text { mobile parts. } \\
\text { Reduced effect of } \\
\text { the shear stress. }\end{array}$ & $\begin{array}{c}\text { High foam } \\
\text { formation under } \\
\text { high gas flow rates. } \\
\text { Poor oxygen transfer } \\
\text { capabilities. } \\
\text { Poor fluid mixing in } \\
\text { highly viscous fluids. } \\
\text { High levels of } \\
\text { foaming under } \\
\text { high-aeration } \\
\text { conditions }\end{array}$ & {$[24,94,116]$} \\
\hline Airlift (ALB) & 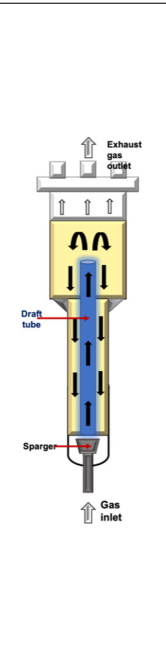 & $\begin{array}{l}\text { It is classified in the } \\
\text { pneumatic-type bioreactor. } \\
\text { This configuration is } \\
\text { considered reasonably like } \\
\text { STR, excepting for the } \\
\text { impeller. They are tower } \\
\text { reactors where fluid broth is } \\
\text { mixed with a gas stream, } \\
\text { which is compressed and } \\
\text { injected at the bottom of the } \\
\text { discharge pipe. The } \\
\text { gas-fluid mix allows the } \\
\text { creation ofdifferences in } \\
\text { density and upward } \\
\text { displacement. It is more } \\
\text { suitable for hairy root and } \\
\text { somatic embryo cultures. }\end{array}$ & $\begin{array}{c}\text { Easy } \\
\text { maintenance and } \\
\text { reduces the risk } \\
\text { of contamination } \\
\text { due to the } \\
\text { absence of } \\
\text { mobile parts. } \\
\text { Reduced effect of } \\
\text { the shear stress. } \\
\text { Higher oxygen } \\
\text { transfer than that } \\
\text { in BC. } \\
\text { The energy } \\
\text { required is } \\
\text { provided by the } \\
\text { compressed gas. }\end{array}$ & $\begin{array}{l}\text { High levels of foam } \\
\text { formation under } \\
\text { high gas flow rates. } \\
\text { Poor fluid mixing in } \\
\text { highly viscous fluids. } \\
\text { Relatively poor } \\
\text { oxygen transfer } \\
\text { capabilities. }\end{array}$ & {$[24,117-119]$} \\
\hline
\end{tabular}


Table 4. Cont.

\begin{tabular}{|c|c|c|c|c|c|}
\hline $\begin{array}{c}\text { Bioreactor } \\
\text { Configuration }\end{array}$ & $\begin{array}{l}\text { Schematic } \\
\text { Diagram * }\end{array}$ & Description & Advantages & Disadvantages & Ref. \\
\hline $\begin{array}{l}\text { Stirred tank } \\
\text { bioreactor } \\
\text { (STB) }\end{array}$ & mestim & $\begin{array}{l}\text { It is grouped in the } \\
\text { mechanically agitated } \\
\text { bioreactor. This bioreactor } \\
\text { consists in a mixer (turbine } \\
\text { or propeller) installed } \\
\text { within the tank reactor and } \\
\text { may be equipped with } \\
\text { gassing inlet stream. It can } \\
\text { operate in batch, } \\
\text { semi-continuous, or } \\
\text { continuous mode }[117,120] .\end{array}$ & $\begin{array}{l}\text { Efficient fluid } \\
\text { mixing systems. } \\
\text { High oxygen } \\
\text { mass transfer } \\
\text { capability. } \\
\text { Convenient for } \\
\text { high-viscous } \\
\text { fluids. } \\
\text { Comply with } \\
\text { Good } \\
\text { Manufacturing } \\
\text { Practices. } \\
\text { Easy scale-up. } \\
\text { Highly adaptable } \\
\text { to production } \\
\text { scale and } \\
\text { products. } \\
\text { Impeller } \\
\text { alternative. }\end{array}$ & $\begin{array}{l}\text { High energy cost } \\
\text { owing to mechanical } \\
\text { agitation. } \\
\text { Contamination risk } \\
\text { with mechanical seal. } \\
\text { Some cells and } \\
\text { metabolites are } \\
\text { susceptible to } \\
\text { shearing generated } \\
\text { by the impeller and } \\
\text { bursting gas bubbles. } \\
\text { Depending on the } \\
\text { operation mode, this } \\
\text { configuration can } \\
\text { represent high costs } \\
\text { of maintenance, } \\
\text { cleaning, and } \\
\text { startup. }\end{array}$ & $\begin{array}{c}{[94,117,120} \\
121]\end{array}$ \\
\hline
\end{tabular}

* Schemes were created with BioRender.com.

Engineering Aspects in the Plant Cell Suspension Culture

Engineers designing or optimizing bioreactor technologies must both consider the effect of operating conditions on the complex interaction between transport phenomena, thermodynamics, growth kinetics, metabolic activity, and maintenance of plant cell cultures and, based on it, propose methodologies to transfer information observed in flask cultures to larger bioreactor scales. Some operational conditions are critical because they can cause a decrease in biomass, a low PDSM production, or a loss of cell viability. Table 5 shows some CSC that have been successfully scaled from flask cultures to large-scale bioreactors.

Table 5. Comparison of operating conditions used for SCC in flask and bioreactor to produce PDSM. The list of examples makes no claim to be complete.

\begin{tabular}{|c|c|c|c|c|c|c|c|}
\hline \multirow{2}{*}{ Species } & \multirow{2}{*}{ Compounds } & \multicolumn{2}{|c|}{ Operation Variables Evaluated } & \multicolumn{2}{|c|}{$\begin{array}{l}\text { Biomass } \\
\text { Production }\end{array}$} & \multirow{2}{*}{$\begin{array}{c}\text { PDSM } \\
\text { Production }\end{array}$} & \multirow{2}{*}{ Ref. } \\
\hline & & In Shake Flask & $\begin{array}{c}\text { In } \\
\text { Bioreactor }\end{array}$ & $\begin{array}{c}\text { In Shake } \\
\text { Flask }\end{array}$ & $\begin{array}{c}\text { In } \\
\text { Bioreactor }\end{array}$ & & \\
\hline $\begin{array}{l}\text { Scrophularia } \\
\text { striata }\end{array}$ & $\begin{array}{l}\text { Phenylethanoid } \\
\text { glycosides }\end{array}$ & $\begin{array}{l}50 \mathrm{~mL} \text { SCC in } \\
100 \mathrm{~mL} \text { flask } \\
110 \mathrm{rpm} \\
25^{\circ} \mathrm{C}\end{array}$ & $\begin{array}{c}5.0 \mathrm{~L} \text { SCC in STR } 10 \mathrm{~L} \\
\text { Fg: } 0.5-1.0 \mathrm{~L} / \mathrm{min} \\
110-170 \mathrm{rpm} \\
25 \pm 1{ }^{\circ} \mathrm{C} \\
\text { Darkness }\end{array}$ & $14.16 \mathrm{~g} / \mathrm{L}$ & $15.64 \mathrm{~g} / \mathrm{L}$ & $\begin{array}{l}\text { The acteoside } \\
\text { content in CSC in } \\
\text { the bioreactor was } \\
\text { about threefold } \\
\text { higher than that in } \\
\text { the shake flask }\end{array}$ & {$[122]$} \\
\hline $\begin{array}{l}\text { Buddleja } \\
\text { cordata }\end{array}$ & $\begin{array}{l}\text { Verbascoside, } \\
\text { linarin and } \\
\text { hydroxycin- } \\
\text { namic acids }\end{array}$ & $\begin{array}{l}50 \mathrm{~mL} \text { SCC in } \\
250 \mathrm{~mL} \text { flasks } \\
110 \mathrm{rpm} \\
26 \pm 2{ }^{\circ} \mathrm{C}\end{array}$ & $\begin{array}{c}\text { STR } 2 \mathrm{~L} \\
\text { Fg: } 1 \text { vvm (ring diffuser } \\
\text { Rushton impeller } \\
400 \mathrm{rpm} \\
26 \pm 2{ }^{\circ} \mathrm{C} \\
\text { 16/8 h light to dark } \\
\text { photoperiod }\end{array}$ & $11.8 \mathrm{~g} / \mathrm{L}$ & $13.62 \mathrm{~g} / \mathrm{L}$ & $\begin{array}{l}\text { The content of } \\
\text { phenolics was } \\
\text { twofold higher } \\
\text { in STR. }\end{array}$ & {$[123,124]$} \\
\hline $\begin{array}{l}\text { Rubia } \\
\text { tinctorum }\end{array}$ & Anthraquinone & $\begin{array}{c}25 \mathrm{~mL} \mathrm{SCC} \mathrm{in} \\
250 \mathrm{~mL} \text { flasks } \\
100 \mathrm{rpm} \\
25 \pm 2{ }^{\circ} \mathrm{C} \\
16 / 8 \mathrm{~h} \text { photoperiod } \\
\left(140 \mu \mathrm{mol} \mathrm{m}^{-2} \mathrm{~s}^{-1}\right)\end{array}$ & $\begin{array}{l}\text { 1.0 L SCC in STR } 2 \mathrm{~L} \\
\text { Fg: } 1 \mathrm{vvm} \\
\text { Turbine impeller } \\
450 \mathrm{rpm} \\
25 \pm 2{ }^{\circ} \mathrm{C} \\
16 / 8 \mathrm{~h} \text { photoperiod } \\
\left(140 \mu \mathrm{mol} \mathrm{m}^{-2} \mathrm{~s}^{-1}\right)\end{array}$ & $330 \mathrm{~g} / \mathrm{L}$ & $220 \mathrm{~g} / \mathrm{L}$ & $\begin{array}{l}\text { Anthroquinone } \\
\text { production was } \\
2.5 \text { times higher } \\
\quad \text { in STR }\end{array}$ & [125] \\
\hline
\end{tabular}


Table 5. Cont.

\begin{tabular}{|c|c|c|c|c|c|c|c|}
\hline \multirow{2}{*}{ Species } & \multirow{2}{*}{ Compounds } & \multicolumn{2}{|c|}{ Operation Variables Evaluated } & \multicolumn{2}{|c|}{$\begin{array}{c}\text { Biomass } \\
\text { Production }\end{array}$} & \multirow{2}{*}{$\begin{array}{c}\text { PDSM } \\
\text { Production }\end{array}$} & \multirow{2}{*}{ Ref. } \\
\hline & & In Shake Flask & $\begin{array}{c}\text { In } \\
\text { Bioreactor }\end{array}$ & $\begin{array}{l}\text { In Shake } \\
\text { Flask }\end{array}$ & $\begin{array}{c}\text { In } \\
\text { Bioreactor }\end{array}$ & & \\
\hline \multirow[t]{2}{*}{ Arnebia sp. } & \multirow[t]{2}{*}{ Shikonin } & $\begin{array}{c}25 \mathrm{~mL} \mathrm{CSC} \mathrm{in} \\
250 \mathrm{~mL} \text { flasks } \\
100 \mathrm{rpm} \\
25 \pm 2{ }^{\circ} \mathrm{C} \\
\text { Continuous light } \\
\left(70 \mu \mathrm{mol} / \mathrm{m}^{2} \mathrm{~s}^{1}\right)\end{array}$ & $\begin{array}{l}\text { Air-lift bioreactor } \\
2 \mathrm{~L} \text { working volume } \\
25 \pm 2^{\circ} \mathrm{C} \\
\text { Fg: } 2 \mathrm{~L} / \mathrm{min} \\
\text { (sparger ring) }\end{array}$ & $1249.2 \mathrm{~g} / \mathrm{L}$ & $480 \mathrm{~g} / \mathrm{L}$ & \multirow{2}{*}{$\begin{array}{l}\text { The shikonin } \\
\text { content was } 2.6 \\
\text { times higher in the } \\
\text { bioreactor than in } \\
\text { the flask. } \\
\text { Production } \\
\text { remained without } \\
\text { significant } \\
\text { differences in both } \\
\text { bioreactors }\end{array}$} & \multirow[t]{2}{*}{ [126] } \\
\hline & & & $\begin{array}{c}\text { STR 2 L } \\
\text { Six-blade turbine } \\
\text { impeller } 100 \mathrm{rpm} \\
\text { Fg: } 2 \mathrm{~L} / \mathrm{min} \\
25 \pm 2{ }^{\circ} \mathrm{C}\end{array}$ & $1249.2 \mathrm{~g} / \mathrm{L}$ & $450 \mathrm{~g} / \mathrm{L}$ & & \\
\hline $\begin{array}{l}\text { Ocinum } \\
\text { basilicum }\end{array}$ & $\begin{array}{l}\text { Rosmarinic } \\
\text { acid }\end{array}$ & $\begin{array}{c}100 \mathrm{rpm} \\
25 \pm 2{ }^{\circ} \mathrm{C}\end{array}$ & $\begin{array}{l}7 \text { L CSC in STR } 10 \mathrm{~L} \\
\text { Marine impeller } \\
100 \mathrm{rpm} \\
\text { Fg: } 25 \mathrm{~L} / \mathrm{min}\end{array}$ & \multicolumn{2}{|c|}{$\begin{array}{c}\text { Biomass was } 8.4 \text { times } \\
\text { higher in bioreactor than } \\
\text { in flask }\end{array}$} & $\begin{array}{c}\text { Production } \\
\text { increased } 1.66 \\
\text { times in bioreactor }\end{array}$ & [69] \\
\hline $\begin{array}{c}\text { Satureja } \\
\text { khuzistanica }\end{array}$ & $\begin{array}{l}\text { Rosmarinic } \\
\text { acid }\end{array}$ & $\begin{array}{l}200 \mathrm{~mL} \mathrm{CSC} \text { in } \\
1 \mathrm{~L} \text { flask } \\
110 \mathrm{rpm} \\
25^{\circ} \mathrm{C}\end{array}$ & $\begin{array}{c}1 \mathrm{~L} \text { CSC in culture bags } \\
2 \mathrm{~L} \\
\text { Batch mode } \\
20-30 \mathrm{rpm} \\
25^{\circ} \mathrm{C} \\
\text { Fg: } 0.1 \mathrm{vvm} \\
\text { Darkness }\end{array}$ & $13.6 \mathrm{~g} / \mathrm{L}$ & $18.7 \mathrm{~g} / \mathrm{L}$ & $\begin{array}{c}\text { Production } \\
\text { increased } 2.5 \text { times } \\
\text { in bioreactor }\end{array}$ & [127] \\
\hline $\begin{array}{c}\text { Vitis } \\
\text { labrusca L. }\end{array}$ & Resveratrol & $\begin{array}{c}100 \mathrm{~mL} \mathrm{CSC} \text { in } \\
300 \mathrm{~mL} \text { flasks } \\
110 \mathrm{rpm} \\
23^{\circ} \mathrm{C} \\
\text { Darkness }\end{array}$ & $\begin{array}{c}\text { STR } 5 \mathrm{~L} \\
\text { Marine impeller } \\
110 \mathrm{rpm} \\
\text { Fg: } 0.15 \mathrm{vvm}\end{array}$ & NR & $\approx 35 \mathrm{~g} \mathrm{DW}$ & $\begin{array}{c}\text { Production } \\
\text { increased } 1.15 \\
\text { times in bioreactor }\end{array}$ & [128] \\
\hline $\begin{array}{l}\text { Santalum } \\
\text { album L. }\end{array}$ & Squalene & $\begin{array}{l}100 \mathrm{~mL} \mathrm{CSC} \mathrm{in} \\
250 \mathrm{~L} \mathrm{flask} \\
90 \mathrm{rpm} \\
28^{\circ} \mathrm{C}\end{array}$ & $\begin{array}{c}\text { Airlift bioreactor } 7 \mathrm{~L} \\
\text { Batch mode } \\
70-80 \mathrm{rpm} \\
\text { Fg: } 4 \mathrm{~L} / \mathrm{min} \\
28 \pm 2^{\circ} \mathrm{C}\end{array}$ & $1.05 \mathrm{mg} / \mathrm{g}$ & $1.25 \mathrm{mg} / \mathrm{g}$ & $\begin{array}{c}\text { Production } \\
\text { increased } 1.71 \\
\text { times in bioreactor } \\
\text { in four weeks of } \\
\text { culture }\end{array}$ & [129] \\
\hline
\end{tabular}

NR means Not reported.

The scaling up of CSC carried out in a flask culture demands the use of bioreactor engineering to characterize the impact of operating conditions on growth kinetics, cell deactivation, and transport phenomena and, hence, on the metabolic activity and production rates of PDSM. To this end, in what follows, main aspects to be considered during the scaling up of CSC, from the screening of plant cells to the industrial-scale bioreactor design, are mentioned and analyzed.

The screening of a set of plant cells is considered as the first stage during the scaling up of CSC $[42,94]$. Screening takes place in shake flasks. In these laboratory bioreactors, hydrodynamic and transport phenomena negatively impact on the growth kinetics, cell viability, metabolic activity, and production rates of PDSM. For instance, in these bioreactors, the production of PDSM involves two-phase systems (liquid culture phase and cell culture phase) neglecting the effect of operating conditions, including the impact of the oxygen concentration, on the microscopic and macroscopic performance of the shake flask. In this context, apparent results regarding cell growth kinetics, cell viability rates, and production rates of PDSM are observed. In these conditions, promising plant cells are identified and selected to be evaluated in larger bioreactor configurations, such as those presented in Table 4.

The second step accounts for characterization of cell growth kinetics, cell viability rates, metabolic activity, and production rates of PDSM under controlled operating conditions in 
bench-scale bioreactors with similar configurations to those systems to be implemented at the commercial scale, i.e., bench-scale bioreactors accounting for three phases (liquidgas-cells) (see Table 4). Thus, during the analysis of bench-scale systems, the coupling of experimentation with mathematical modeling is essential for stating the basis for the scaling up of CSC [130-132]. Herein, cell growth kinetics and production rates of PDSM are the main response variables to maximize during CSC. It is worth mentioning that their experimental and theoretical characterization makes possible the connection between the microscopic world of the metabolic cell activity and the macroscopic world of the bioreactor performance and, hence, the downstream processing. Besides, the experimental characterization of these cell mechanisms and their analysis using mathematical models lead to the construction of the engineering tool for the scaling up and optimization of the bioreactor configuration, allowing a better understanding of CSC during the production of PDSM. In particular, the use of bench-scale bioreactors allows for identifying and controlling those operating conditions where transport phenomena favor the kinetics of the CSC.

Based on the kinetics, since in CSC it is not possible to develop intrinsic kinetic models, there are two types of models that can be developed in bench-scale bioreactors: extrinsic ones, where transport phenomena are explicitly included during the modeling of the bioreactor; and apparent ones, where transport phenomena resistances impact during the experimentation but they are not considered during the modeling of the bench-scale bioreactors [131,133-137]. Thus, to determine extrinsic kinetic models, it is recommended to carry out a regime analysis to identify and model those transport phenomena limiting the production of PDSM. Experiments make possible the development of the corresponding model, relating kinetics with macroscopic variables, namely the concentration of substrates and PDSM, cell growth, and cell viability involved during the operation of the bench-scale bioreactor. The kinetic model depends on the quality of the experimental data and it is only reliable for the range of operational conditions utilized during its development. When the kinetic model is based on metabolic steps of the reaction, the mathematical complexity increases but leads to a better physical representation of the CSC during the production of PDSM. Besides, the loss of cell viability caused by operational aspects, i.e., a toxic compound, cell shear stress, or cell sintering, is modeled by empirical expressions whose parameters involve physical meaning [138], such as the generalized power law equation (GPLE) [139-141]. Finally, the Monod model offers an adequate explanation for the reaction rates of growing cells, but it has no mechanistic basis [142,143]. Moreover, the Monod model is only applicable when cells are in a metabolic equilibrium, namely when the composition of the macromolecules in the cell remains in a pseudo-steady state during the CSC. Table 6 presents some kinetic models to describe cell growth rate. It is worth mentioning that, in transient experiments, when the concentration of a substrate or PDSM is brusquely modified, Monod kinetics are not suitable and the kinetic model must account for the cell metabolism $[138,144]$. There are, in the literature, several models that have no mechanistic grounds but account for some biological features of the cell growth $[138,145]$. These models offer an acceptable description of the cell growth and metabolic activity due to fluctuation in the concentration of substrates and products. In these models, cell mass is divided into compartments, and the rate of formation of each compartment has different stoichiometry and kinetics. 
Table 6. Models used to describe kinetics and deactivation in whole cells [137,140-142].

\begin{tabular}{cc}
\hline Mathematical Equation & Conventional Name \\
\hline$r_{\mathrm{x}}=\mu=\frac{\mu_{\max }\left[\mathrm{S}_{\mathrm{i}}\right]}{\left[\mathrm{S}_{\mathrm{i}}\right]+\mathrm{K}_{\mathrm{m}}}$ & Monod kinetics \\
$\mathrm{r}_{\mathrm{s}}=\mathrm{Y}_{\mathrm{xs}} \mu$ & \\
\hline $\mathrm{r}_{\mathrm{x}}=\mu=\frac{\mu_{\max }\left[\mathrm{S}_{\mathrm{i}}\right]}{\left(\left[\mathrm{S}_{\mathrm{i}}\right]^{2} / \mathrm{K}_{\mathrm{i}}\right)+\left[\mathrm{S}_{\mathrm{i}}\right]+\mathrm{K}_{\mathrm{m}}}$ & Expanded Monod kinetics \\
$\mathrm{r}_{\mathrm{s}}=\mathrm{Y}_{\mathrm{xs}} \mu$ & \\
\hline $\mathrm{r}_{\mathrm{x}}=\mu=\frac{\mu_{\max }\left[\mathrm{S}_{\mathrm{i}}\right]}{\left[\mathrm{S}_{\mathrm{i}}\right]+\mathrm{K}_{\mathrm{m}}}\left(1-\frac{[\mathrm{P}]}{[\mathrm{P}]_{\max }}\right)$ & Expanded Monod kinetics \\
$\mathrm{r}_{\mathrm{s}}=\mathrm{Y}_{\mathrm{xs}} \mu$ & \\
\hline $\mathrm{r}_{\mathrm{x}}=\mu=\mu_{\max }\left(1-\exp \left(-\left[\mathrm{S}_{\mathrm{i}}\right] / \mathrm{K}_{\mathrm{m}}\right)\right)$ & Monod's teacher Tessier kinetics. \\
$\mathrm{r}_{\mathrm{s}}=\mathrm{Y}_{\mathrm{xs}} \mu$ & \\
\hline $\mathrm{r}_{\mathrm{x}}=\mu=\frac{\mu_{\mathrm{max}}\left[\mathrm{S}_{\mathrm{i}}\right]}{\left[\mathrm{S}_{\mathrm{i}}\right]+\mathrm{K}_{\mathrm{S}} \mathrm{X}}$ & Contois kinetics. \\
$\mathrm{r}_{\mathrm{s}}=\mathrm{Y}_{\mathrm{xs}} \mu$ & \\
\hline $\mathrm{r}_{\mathrm{x}}=\mu=\mu_{\max }\left(1-\frac{\mathrm{X}}{\mathrm{K}_{\mathrm{s}}}\right)$ & Logistic kinetics. \\
$\mathrm{r}_{\mathrm{s}}=\mathrm{Y}_{\mathrm{xs}} \mu$ & \\
\hline$\frac{\mathrm{d} \theta_{\mathrm{x}}=-\mathrm{k}_{\mathrm{in}}\left(\theta_{\mathrm{x}}-\theta_{\mathrm{ss}}\right)^{\mathrm{m}}}{\mathrm{dt}}$ & \\
$\mathrm{r}=\mathrm{r}_{\mathrm{s}}=\theta_{\mathrm{x}} \frac{\mathrm{k}\left[\mathrm{S}_{\mathrm{i}}\right]}{\left.\mathrm{S}_{\mathrm{i}}\right]+\mathrm{K}_{\mathrm{m}}}$ & Cell deactivation kinetics \\
\hline
\end{tabular}

In bench-scale bioreactors, it is experimentally complicated to minimize transport resistances [139-141,146]. In the fluid bulk, concentration, temperature, or radiative gradients can be present. Hydrodynamics impact on mass and heat transfer mechanisms from the gas phase to the liquid phase and from the liquid phase to the cell phase. Moreover, cell growth can impact on mass and heat transfer mechanisms. Although complicated, a proper kinetic analysis must account for the effect of fluid dynamics on transport phenomena and, hence, on cell growth, cell viability, and metabolic activity.

During the screening at the laboratory bioreactors or during the operation of the bench-scale bioreactor, the response surface methodology (RSM) is a potential tool to guide experimental designs. RSM leads to the following advantages [147-151]:

(1) It defines an establishment of the relationship between responses (yield, cell viability, oxygen concentration, etc.) and control operating conditions (temperature, pressure, initial concentration, power input, agitation rate, etc.).

(2) It predicts the effect of control operating condition on responses.

(3) It gives inferences on the significance of the operating conditions on the performance of the reactor.

(4) It allows the determination of the operating window where the bioreactor meets its best performance.

On the above end, RSM couples experimental designs, and mathematical and statistical methods [152,153]. Firstly, an experimental design is proposed; the evaluation of this experimental design constitutes the so-called response surface design (RSD). The suitability of the RSD depends on its orthogonally, ratability, and uniform precision [153]. Secondly, the empirical model is then developed; it is approximated by a polynomial equation that accounts for elements that consist of powers and cross-product powers, constant coefficients referred to as parameters, and a random experimental error. Albeit empirical, first-degree and second-degree polynomial equations are usually used to fit observations and carry out the optimization. To this end, every model and its reliability depends on the RSD, i.e., first-order designs are used to fit observations with the first-degree models, and observations out of second-order designs are fitted with second-degree models [152-154]. The most common first-order designs are $2 \mathrm{k}$ factorial, Plackett-Burman, and simplex designs, while the most common second-order designs are $3 \mathrm{k}$ factorial, central composite, and the Box-Behnken designs. Note that the choice of a proper RSD is essential since the quality of prediction, as measured by the size of the prediction variance, depends on it; thus, the 
lower the variance, the better the fit of the responses. On this basis, a single RSD is not able to satisfy all criteria, but it is considered as robust if it meets the assumptions related to the model and the error distribution [152,153]. Finally, the assessing of the results uses both statistical tests, i.e., F-value, $\mathrm{t}$-value, and confidence interval, and graphical tests, i.e., variance dispersion graphs, fraction of design space plots, and quantile plots. Graphical methods $[149,150]$ based on quantile dispersions have also been used to compare experimental designs for estimating variance components in an analysis of variance (ANOVA) situation. RSM can lead to the identification of the operational window where CSC presents its higher yields to PDSM, which, in turn, will be essential in the conceptual design and scaling up of the bioreactor configuration.

Because of the advent of computation in the last years, the bioreactor design not only depends on empirical, but also deterministic approaches, which allows the proper determination of hydraulics, fluid dynamics, mass transport, heat transfer, radiative transfer, and kinetics from different bioreactor configurations at various scales. This information is transferred to design and scale up the industrial bioreactor. The design of this reactor strongly depends on the development of a model coupling kinetics and transport phenomena at both the cell and bioreactor level, including the fluid and the gas phase. This is, however, a complex task, since it needs experiments and mathematical solutions that are not trivial. It is worth stressing that, during the construction of this model, fluid dynamics are yet the bottleneck during the scaling up of a bioreactor configuration because of their impact on transport phenomena, kinetics, and, hence, on the global production of PDSM.

Based on the above, a model accounting for kinetic, deactivation, and all transport mechanisms should be developed from the laboratory to the bench scale. This model should be constructed following a framework based on computational fluid dynamics (CFD). The model needs to be validated at the bench scale before using it to design the industrial bioreactor. The preliminary dimensions of the reactor need to be obtained from the utilization of the practical know-how reported in the literature or experimental and modeling results obtained at the bench scale. It will make the scaling up process more efficient and reliable. Developing a model for the use of CFD allows the consideration of fluid dynamics along with its effect on transport phenomena, which leads to obtaining operating conditions where mixing, hydrodynamics, and transport phenomena are improved without affecting the operating cost of the process. A criterion when designing the industrial-scale bioreactor is to achieve a compromise between operating expenses and yield of the PDSM. At the end of the scaling-up process, the experimentation and investment cost as that compared using an empirical or heuristic approach will be significantly minimized.

In addition to the aforementioned, the scaling up of CSC becomes more challenging when observing how operating conditions impact on the production of PDSM. Operating conditions influence in different scenarios and magnitudes the performance of cell cultures during the production of PDSM, from the supply of nutrients (oxygen, light, ionic strength, $\mathrm{pH}$ ) to the implementation of mechanical and pneumatic work to keep the process operating in optimal conditions. In further sections, a discussion about the main operating variables in bioreactors and their effect on the performance of cell culture will be provided.

\subsection{Effect of Operating Variables on the Bioreactor Performance}

\subsubsection{Temperature}

It is a key variable that must be kept under control because its increment impacts on kinetics, inducing the premature senescence of the culture, and produces the loss of viability, such that it reduces the yield of PDSM. On the other hand, temperature may also act as an abiotic elicitor. Temperature in bioreactors has varied between 23 and $30{ }^{\circ} \mathrm{C}[155,156]$, although most of the works have fixed it at $25^{\circ} \mathrm{C}[122,123]$. Most temperature control systems consist of the use of temperature probes and jackets or coils used as a heat transfer system to activate metabolic reactions or cool the bioreactor because of the heat generated by exothermic metabolic reactions. Heating or cooling systems also used in bioreactors are electric heaters or steam streams for the former, and cooling water or refrigerants in 
cooling towers for the latter [115]. Species such as Catharanthus roseus and Lavanda vera exhibited the best kinetic cell performance at $30^{\circ} \mathrm{C}$, leading to a constant production rate of PDSM when CSC was carried out in stirred tank bioreactors [157,158].

\subsubsection{Light}

Cell irradiation by use of visible light is one of the most important elements when designing CSC bioreactors, since photons affect the growth and morphogenesis of cell cultures both in in vivo and in vitro conditions. Plant cell cultures vary their physiological response to the light exposure because of photolytic reactions, significantly influencing the synthesis and production of secondary metabolites, such that yields are a function of the type of species, growth stage, type of light, and time of exposure to light. In plant cell cultures, the use of $12 / 16 \mathrm{~h}$ light/dark photoperiod is the most frequent condition, although total darkness and continuous light exposure have also been reported $[52,159,160]$. Some examples recently reported in the literature about the effect of light exposure in CSC are for Vitis vinifera [159], Theobroma cacao [161], Clinacanthus nutans (Burm. f.) Lindau [162], Catharanthus roseus (L.) G Don. [163], and Artemisia absinthium [164], where higher production of PDSM were obtained under light exposure. On the other hand, species such as Plumbago europaea L. [160] showed 1.7 times the production of plumbagina, the main bioactive compound, when CSC were cultured in darkness; besides, Ajuga bracteosa exhibited a higher concentration of PDSM and antioxidant activity when its CSC was subjected to darkness and methyl jasmonate as elicitor [165], and Ruta graveolens with a 3.14-fold increase in total flavonoid content [166].

\subsection{3. $\mathrm{pH}$}

$\mathrm{pH}$ is one of the factors influencing the growth and production rates of PDSM; therefore, it is a critical operating condition in small- and large-scale plant cell culture. It provides the proper balance of acidity/alkalinity to the culture to avoid cell breakage. The initial $\mathrm{pH}$ in plant cell cultures usually ranges between 5.5 and 6.0; abrupt changes during the culture can cause variations or loss of the nutrient uptake. One of the most relevant challenges during the operation of the bioreactor is the successful implementation of an efficient $\mathrm{pH}$ control system. The bioreactor behavior depends on the change in $\mathrm{pH}$, modifying the cell growth and the production of PDSM and being widely dependent of the species related to the plant $[13,156,167,168]$.

\subsubsection{Mixing}

In cell cultures, the production of biomass and PDSM is highly dependent on the conversion of substrates into products, this conversion and reaction rates are mediated and controlled by transport mechanisms toward and from the place where the conversion occurs. In every bioreactor, fluid dynamics impact how substrate and inoculum are transported to the liquid bulk and how PDSM are removed. In batch operations, fluid dynamics occasioned by mixing prevents local exhaustion of substrates such as oxygen [169]. Mixing and fluid dynamics are a function of the bioreactor configuration and impact the performance of CSC, such that, when properly controlled, they minimize interfacial mass and heat transport resistances, decreasing temperature and concentration gradients in the bioreactor bulk and, hence, having homogeneous distribution of the components or conditions in the culture medium [170].

The characteristic time related to mixing in bioreactors influences heat production, oxygen mass transfer, and C-substrate consumption in the cultures [24,169]. For instance, the characteristic time related to heat production (mainly due to metabolic heat) is defined as the time necessary to heat up the content in the vessel by $1{ }^{\circ} \mathrm{C}$, while the mixing characteristic time is usually considered as the one for smoothing out temperature gradients occasioned by the metabolic reactions. In most bioreactor configurations, mixing times range from 10 to $100 \mathrm{~s}$, such that heat will not be accumulated. 
The characteristic time for mass transport is defined as the characteristic time required for the decrease in oxygen concentration once the gas flow rate is discontinued, this time is not related to a critical time for the micro-organism. Depending on the bioreactor configuration, the capacity of oxygen transfer rate (OTR) will vary [170]. Despite STR exhibiting better OTR, it has some restrictions related to the dispersion of gas through the vessel, because the higher transfer occurred near the sparger, reducing the concentration of dissolved oxygen in the aqueous medium. In this sense, the respective characteristic time for oxygen depletion in STR is considered as the critical time when it is assumed that all the oxygen is transferred close to the impeller. On the other hand, bubble column bioreactors are not excluded for exhibiting oxygen depletion; in this configuration, the oxygen is transferred at all the positions in the column, and even though the oxygen transfer is mainly observed near the sparger, it is greater than that for STR. Thus, the characteristic time for depletion is based on the concentration of oxygen dissolved outside the region of the sparger [170-172].

The last characteristic time associated to the mixing process in bioreactors is related to the relationship between cell growth rate and bulk substrate concentration. Since the Monod model describes adequately this phenomenon, this equation is used to determine the characteristic time for substrate consumption. This characteristic time will be larger than the one for mixing time and fluid dynamics calculated for the bioreactor. Thus, cell growth rate and consumption substrate rate strongly depend on the transport phenomena resistances and, hence, characteristic times involved in every bioreactor configuration.

\section{Considerations of Cell Culture Properties on the Mixing Process}

Plant CSC is effectively set up in small-scale bioreactors, exhibiting excellent production of secondary metabolites, but, when it comes to working with larger scales, the situation is not that simple. Cell cultures tend to form flocs and agglomerates when the daughter cells are not completely separated from the stem ones after cell division; these agglomerate systems are constituted from several hundreds of cells, ranging in particle sizes around $0.5 \mathrm{~cm}$ diameter, depending on the cell line, culture conditions, and growth stage $[16,111,173]$. These agglomerated structures lead to the formation of heterogeneous populations creating microenvironments (larger intra-agglomerate transport resistances) that limit the substrate and oxygen transfer rates, causing low rates of growth and PDSM production. Some studies have demonstrated that the production of specialized high value-added PDSM depends on the formation of aggregates and their size [174-177]. For example, growth characteristics and qualitative composition of PDSM in Phlojodicarpus sibiricus cell cultures were directly correlated with the level of cell aggregation, being more favorable in aggregates of 10-30 cells than in aggregates of $>50$ cells [174]. Small aggregates $(\sim 400 \mu \mathrm{m})$ within Taxus suspension cultures produced four times more paclitaxel than larger aggregates $(\sim 1100 \mu \mathrm{m})[178]$.

However, despite intra-aggregate diffusion limitations, it has been reported that the formation of large aggregates may favor the production of PDSM, as is the case with cell suspension cultures of Psoralea corylifolia, where an aggregate size of 1200-2000 $\mu \mathrm{m}$ favored the production of phytoestrogens compared to sizes of 800-1200 $\mu \mathrm{m}$ [179]. Moreover, the formation of cell aggregates can also be favored by the secretion of extracellular polysaccharides (ECP), contributing to greater cell adhesion. Therefore, aggregation patterns coupled with high biomass concentrations and ECP secretions result in culture mediums with non-Newtonian characteristics [180].

One of the most logical and simplest ways to overcome these concerns could be related to the increase in the stirring speed, because it will break the flocs and cell agglomerates, facilitating the substrate and oxygen uptake and, therefore, increasing the growth rate and conversion to desired products [174,181]. Nevertheless, plant cells, as with other micro-organisms, are sensitive to shearing, and surpassing their resistance umbral to hydrodynamic stress may induce their cell wall breakage, causing the loss of valuable products $[124,180,182]$. Besides, plant cell cultures are characterized by being viscous and 
highly dense suspensions that behave as non-Newtonian fluids, which also contributes to restricting the flow regime and the heat and mass transfer mechanisms, leading to zones with gradients of concentration and temperature, and, therefore, to dead zones of mixing in the bioreactor $[42,173]$. For this reason, in CSC the mixing is often evaluated in terms of its impact on the biological performance (growth rate and productivity) of the bioreactor technology.

A clear example that the aggregate size is an important parameter for the production of high added-value PDSM is the production of Paclitaxel by Taxus chinensis cultures. The authors of $[176,181]$ showed that mechanical shear helps disintegration, favoring production by having small aggregates $(194 \mu \mathrm{m})$ compared to the control, in which large aggregates $(600 \mu \mathrm{m})$ were obtained that directly affected production.

\subsubsection{Aeration}

Aeration, as well as mixing, is one of the most important operating variables, both acting synergistically in bioreactors by maintaining aerobic conditions [183], helping to desorb volatile products, eliminating the metabolic heat, contributing to the synthesis of PDSM, and having a beneficial effect on power consumption [10]. In most of bioreactor configurations, gas stream is split by highly porous spargers in the form of bulb diffusers, sintered filters, or perforated plates, where gas bubbles are generated on the bottom of the vessel and rise through the culture medium, producing pneumatic mixing. The mass transfer will depend on the type of sparger and gas flow rate. Despite physiological differences between microbial and plant cell cultures, the use of excessive aeration conditions might cause foam generation due to the presence of extracellular proteins [184].

CSC in plants generally exhibits a doubling time of about $2-5$ days, longer than that required by bacteria cells $(0.5-1 \mathrm{~h})[42,185]$. For this reason, slower growth rates in plant cells lead to low oxygen demand, with a direct relationship to the cell concentration. High cell densities in the bioreactors may not be as desirable because it can cause limitations and inadequate concentrations of dissolved oxygen. The oxygen uptake rate (OUR) in CSC is commonly used for monitoring the physiology and oxygen demand by plant cells; this parameter is dependent on the cell culture line, culture conditions, and the growth rate [170]. Typical OUR values for plant CSC range from 5 to $10 \mathrm{mmol}_{2} / \mathrm{L} \mathrm{h}$ ), a lower requirement when compared to that for microbial cells (10-90 mmol $\left.\mathrm{O}_{2} / \mathrm{L} \mathrm{h}\right)$. Another important parameter considered for the establishment of aeration conditions is the oxygen transfer rate (OTR); it must be high enough to provide the required oxygen concentration to meet the respiratory demands of the cells (OUR), favoring the growth and production of the desired compounds, but not too high that it can hinder them. To overcome these difficulties, the concentration of dissolved oxygen must be kept above the critical level of cell oxygen consumption, which has been reported to be $15-20 \%$ oxygen saturation content in pure water $\left(1.3\right.$ to $\left.1.6 \mathrm{~g} / \mathrm{m}^{3}\right)$ [11,77]. Dissolved oxygen concentration is not a variable that can be used for scaling criteria, and instead the volumetric mass transfer coefficient $(\mathrm{kLa})$ and the air flow rate are used (vvm). kLa is a function of both agitation and aeration and is affected by various factors, such as geometric and operational characteristics of the reactor (stirring speed, aeration rate, fluid hydrodynamics, media composition, cell type, morphology, and concentration), which must, therefore, be analyzed when designing the bioreactor [186]. In agreement to the literature [24], to achieve an OUR around 5 to $10 \mathrm{mmol} \mathrm{O}_{2} / \mathrm{L} \mathrm{h}$ ) in plant CSC, a typical kLa value between 10 and $50 \mathrm{~h}^{-1}$ is required. In Table 7 , some of the operating conditions used in bioreactors and their effect on the CSC are described.

Other variables related to the aeration process in bioreactors are the superficial velocity of the gas, which permits the calculation and inference of the air bubbles' behavior in the bioreactor, and the observation of their coalescence in the medium. The superficial velocity is controlled by the aeration rate $[119,187]$ showed that plant cell cultures, when subjected to hydrodynamic stresses, can change their color and increase the PDSM production as a defense mode. Nevertheless, as mentioned above, aeration also has an effect on the mixing 
and mass transfer, so low aeration conditions will lead to poorly homogeneous conditions and limitations on cell growth due to the presence of sedimentation, or the development of microenvironments due to concentrations gradients. On the other hand, the increase in aeration could overcome these disadvantages, but also, the increase in shearing occurrs, making it necessary to establish the fragility of the cells to define the intensities of aeration that maintain an adequate level of homogeneity, without affecting the cell growth nor the production of PDSM.

Table 7. Conditions used in bioreactors and their effect on the SCC.

\begin{tabular}{|c|c|c|c|c|c|c|}
\hline Species & Compounds & Bioreactor & Operating Conditions & $\begin{array}{l}\text { Operation } \\
\text { Variables }\end{array}$ & $\begin{array}{c}\text { Effect of the } \\
\text { Operating Variable }\end{array}$ & Ref. \\
\hline B. cordata & $\begin{array}{l}\text { Phenolics } \\
\text { (phenylethanoid } \\
\text { glycoside and } \\
\text { flavonoid } \\
\text { contents) }\end{array}$ & $\begin{array}{l}\text { STR of } 2 \text { L (ring } \\
\text { diffuser) and } 3 \mathrm{~L} \\
\text { (sintered diffuser), } \\
\text { Rushton impeller }\end{array}$ & $\begin{array}{c}26 \pm 2{ }^{\circ} \mathrm{C}, \text { photoperiod of } \\
16 \mathrm{~h} \text { light }\left(50 \mu \mathrm{mol} / \mathrm{m}^{2}\right. \\
\text { s) } / 8 \mathrm{~h} \text { darkness } \\
\text { Fg: } 0.1 \mathrm{vvm}\end{array}$ & $\begin{array}{l}\text { Stirring } \\
\text { speeds }(120 \\
\text { and } 400 \\
\text { rpm) }\end{array}$ & $\begin{array}{l}\text { In both bioreactors, a higher } \\
\text { shear stress was observed at } \\
\text { rates of } 400 \mathrm{rpm} \text {, affecting the } \\
\text { growth phases and parameters, } \\
\text { resulting in the decrease in } \\
\text { PDSM. }\end{array}$ & [124] \\
\hline R. cordifolia & Anthraquinones & STR of $8 \mathrm{~L}$ & $\begin{array}{c}25 \pm 0.1^{\circ} \mathrm{C}, \\
\text { gamma-irradiated cell } \\
\text { cultures, the agitation } \\
\text { speed of the impeller was } \\
60 \mathrm{rpm} \text {, working volume } \\
5 \mathrm{~L}\end{array}$ & $\begin{array}{l}\text { Impeller } \\
\text { type } \\
\text { (helical } \\
\text { ribbon, } \\
\text { Rushton } \\
\text { turbine) }\end{array}$ & $\begin{array}{l}\text { Helical ribbon provided a } \\
\text { homogeneous mix and lower } \\
\text { shear stress compared to } \\
\text { Rushton turbine. }\end{array}$ & [66] \\
\hline R. tinctorum & Antraquinones & Baffled flask & $\begin{array}{c}25 \pm 2{ }^{\circ} \mathrm{C} \text {, the cultures } \\
\text { were grown in presence or } \\
\text { in absence of light with a } \\
16 \mathrm{~h} \text { photoperiod using } \\
\text { cool white fluorescent } \\
\text { tubes at a light intensity of } \\
\text { approximately } 90 \mathrm{~mol} / \mathrm{m}^{2} \\
\mathrm{~s}\end{array}$ & $\begin{array}{l}\text { Stirring } \\
\text { speeds }(100, \\
360 \mathrm{rpm})\end{array}$ & $\begin{array}{c}\text { The speed at } 360 \text { rpm had a } \\
\text { negative effect on cell growth; } \\
\text { however, it favored the } \\
\text { production of PDSM }\end{array}$ & [188] \\
\hline R. tinctorum & Antraquinones & $\begin{array}{l}\text { STR of } 1.5 \mathrm{~L}, \\
\text { turbine impeller }\end{array}$ & $\begin{array}{c}25 \pm 2{ }^{\circ} \mathrm{C} \text {, working } \\
\text { volume of } 1.0 \mathrm{~L} \\
\text { Fg: } 1 \mathrm{vvm}\end{array}$ & $\begin{array}{l}\text { Shear stress } \\
(450 \mathrm{rpm})\end{array}$ & $\begin{array}{l}\text { The speed of agitation affected } \\
\text { cell viability; however, it favored } \\
\text { the production of PDSM. }\end{array}$ & [125] \\
\hline \multirow[t]{2}{*}{ Arnebia sp. } & \multirow[t]{2}{*}{ Shikonin } & Air-lif of 2 L & $\begin{array}{c}25 \pm 2{ }^{\circ} \mathrm{C}, \text { the dissolved } \\
\text { oxygen }(2 \mathrm{~L} / \mathrm{min})\end{array}$ & \multirow[t]{2}{*}{$\begin{array}{l}\text { Bioreactor- } \\
\text { type }\end{array}$} & \multirow{2}{*}{$\begin{array}{l}\text { No significant differences were } \\
\text { obtained in the growth and } \\
\text { production of PDSM in both } \\
\text { bioreactors. }\end{array}$} & \multirow[t]{2}{*}{ [126] } \\
\hline & & $\begin{array}{l}\text { STR of } 2 \mathrm{~L}, \\
\text { six-blade turbine } \\
\text { impellers }\end{array}$ & $\begin{array}{c}25 \pm 2{ }^{\circ} \mathrm{C}, 100 \mathrm{rpm}, \\
\text { dissolved oxygen }(2 \\
\mathrm{L} / \mathrm{min})\end{array}$ & & & \\
\hline
\end{tabular}

\begin{tabular}{ccc}
\hline & $\begin{array}{c}\text { Phenylpropanoid } \\
\text { glycosides } \\
\text { Verbascoside) }\end{array}$ & STR \\
V. officinalis & (Isoverbascoside) & \\
\cline { 2 - 3 } & $\begin{array}{c}\text { Phenolic acids } \\
\text { (Ferulic and } \\
\text { Rosmarinic acid) }\end{array}$ & Balloon \\
bioreactor (BB)
\end{tabular}

\section{$23 \pm 1{ }^{\circ} \mathrm{C}$, photoperiod,}

$33 \mathrm{rpm}$ and continuous Fg: 0.5 vvm Bioreactor-
type
The production of PDSM was significantly higher in the STR bioreactor

\begin{tabular}{|c|c|c|c|c|c|c|}
\hline \multirow[b]{2}{*}{ T.minus } & \multirow[b]{2}{*}{ Berberine } & \multirow[b]{2}{*}{$\begin{array}{c}\text { STR of } 2 \mathrm{~L}, \\
\text { Rushton turbine }\end{array}$} & $\begin{array}{c}25^{\circ} \mathrm{C} \text { in the dark, } \\
\text { working volume }(1.75 \mathrm{~L}) \\
\text { Fg: } 0.1 \mathrm{vvm}\end{array}$ & $\begin{array}{l}\text { Stirrer } \\
\text { speeds of } \\
100-900 \\
\text { rpm }\end{array}$ & $\begin{array}{l}\text { The } 250 \text {-rpm speed favored cell } \\
\text { growth and PDSM production }\end{array}$ & \multirow[b]{2}{*}{ [77] } \\
\hline & & & $\begin{array}{l}25^{\circ} \mathrm{C} \text { in the dark, } \\
\text { working volume }(1.75 \mathrm{~L}) \\
\text { and } 250 \mathrm{rpm} \\
\mathrm{Fg}: 0.1 \mathrm{vvm},\end{array}$ & $\begin{array}{l}\text { Dissolved } \\
\text { oxygen } \\
\text { fluctua- } \\
\text { tions }(25,35 \\
\text { and } 50 \%)\end{array}$ & $\begin{array}{l}\text { Fluctuations in dissolved } \\
\text { oxygen tension affected } \\
\text { berberine accumulation in the } T \text {. } \\
\text { minus cultures depending on the } \\
\text { average oxygen level achieved. } \\
\text { Reductions in berberine } \\
\text { production were observed not } \\
\text { only as the average dissolved } \\
\text { oxygen tension declined below } \\
35 \% \text { air saturation }\end{array}$ & \\
\hline
\end{tabular}


Table 7. Cont.

\begin{tabular}{|c|c|c|c|c|c|c|}
\hline Species & Compounds & Bioreactor & Operating Conditions & $\begin{array}{l}\text { Operation } \\
\text { Variables }\end{array}$ & $\begin{array}{c}\text { Effect of the } \\
\text { Operating Variable }\end{array}$ & Ref. \\
\hline D. deltoidea & Steroid glycosides & $\begin{array}{l}\text { BC of } 20 \text { and } \\
630 \mathrm{~L}\end{array}$ & $\begin{array}{c}26 \pm 0.5^{\circ} \mathrm{C} \text { in darkness, } \\
\text { working volume of } 15 \mathrm{~L} \\
\text { and } 550 \mathrm{~L} \text {, } \\
\text { semi-continuous regime. } \\
\text { Fg: } 0.1 \text { to } 1.0 \mathrm{vvm} \\
\text { depending on the growth } \\
\text { phase of cell culture, OD } \\
\text { was maintained at } 10-40 \% \\
\text { of saturation volume }\end{array}$ & $\begin{array}{l}\text { Bioreactor } \\
\text { volume }\end{array}$ & $\begin{array}{l}\text { No significant effect of } \\
\text { bioreactor volume was obtained } \\
\text { on cell growth and PDSM } \\
\text { production. }\end{array}$ & [182] \\
\hline
\end{tabular}

PDSM: plant-derived secondary metabolites; STR: stirred tank reactor; Fg: aeration flow rate; vvm: gas volumetric flow rate per unit volume of culture medium.

\section{Conclusions}

To conclude, plants are a rich source of bioactive compounds of pharmacological interest, known as PDSM; due to their low production in nature, obtaining them leads to overexploitation and extinction of the species of interest. As an alternative ecological solution, plant cell culture, particularly CSC, stands out as one of the most efficient and promising technologies for producing PDSM in bioreactors. The selection and design of the bioreactor for the production of PDSM out of CSC is a complex task, which depends on two factors: on the one hand, the properties of the cells that vary according to the species under study (shear stress, aggregate formation, and rheology) and, on the other hand, transport phenomena related to the bioreactor configuration. The operating conditions in the bioreactor impact cell performance, such that the mixing and aeration are factors influencing fluid dynamics and, hence, mass transfer and heat transfer at both inter- and intracell levels. Thus, the optimization of bioreactors by elucidating the effect of the operating condition on the cell properties is essential for obtaining larger yields of PDSM. Despite the arduous research in this field, few PDSMs are commercialized at an industrial level. To this end, more studies focused on correlating the operating variables with kinetics and transport phenomena are needed to understand the behavior of plant cells, providing more bases for optimal growth and maximum production of PDSM in bioreactors.

This review provided updated information that helps the reader to understand the behavior of plant cells growing in suspension, identifying the key parameters to relate PDSM productivity with the optimization of operating variables in bioreactors, which will help future research in the scaling of PDSM with high added value, resulting in the development of new successful biotechnological processes.

Author Contributions: Conceptualization, E.A.M.-A., A.R.-G. and F.C.-S.; investigation, E.A.M.-A.; resources, F.C.-S., M.R.-M.; writing-original draft preparation, E.A.M.-A.; writing-review and editing, A.R.-G., C.O.C.-A. and F.C.-S.; project administration, F.C.-S. All authors have read and agreed to the published version of the manuscript.

Funding: This research was partially funded by the Consejo Nacional de Ciencia y Tecnología (CONACyT), scholarship grant of E.A.M.-A. (616138).

Acknowledgments: The authors give thanks to the Consejo Nacional de Ciencia y Tecnología (CONACyT) for the scholarship grant of E.A.M.-A. (616138).

Conflicts of Interest: The authors declare no conflict of interest. 


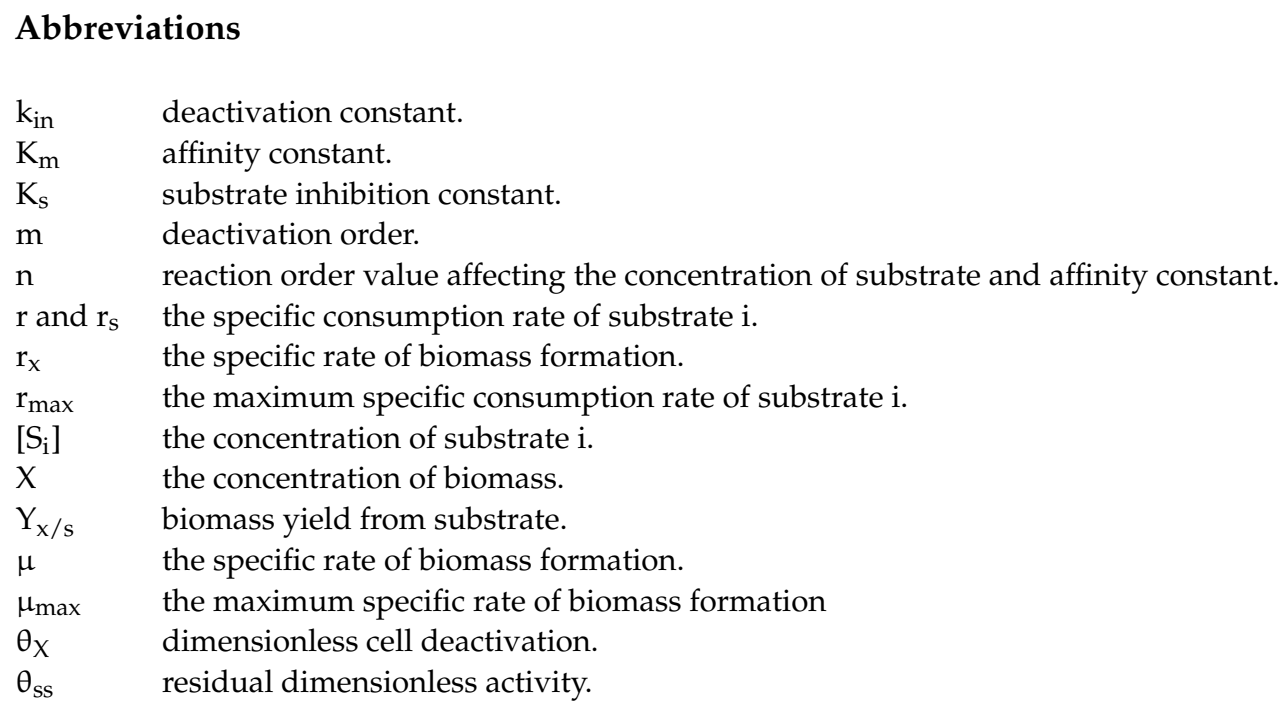

\section{References}

1. Zafar, T.; Shrivastava, V.K.; Shaik, B. Pharmaceutical Biotechnology in Herbal Neuroprotection; Springer: Singapore, 2018; pp. 221-228.

2. Süntar, I. Traditional Medicine for Wound Management. Evid.-Based Complement. Altern. Med. 2017, $2017,4214382$.

3. Elkordy, A.A.; Haj-Ahmad, R.R.; Awaad, A.S.; Zaki, R.M. An overview on natural product drug formulations from conventional medicines to nanomedicines: Past, present and future. J. Drug Deliv. Sci. Technol. 2021, 63, 102459. [CrossRef]

4. Georgiev, M.I.; Eibl, R.; Zhong, J.-J. Hosting the plant cells in vitro: Recent trends in bioreactors. Appl. Microbiol. Biotechnol. 2013, 97, 3787-3800. [CrossRef]

5. Steingroewer, J.; Bley, T.; Georgiev, V.; Ivanov, I.; Lenk, F.; Marchev, A.; Pavlov, A. Bioprocessing of differentiated plant in vitro systems. Eng. Life Sci. 2013, 13, 26-38. [CrossRef]

6. Bhaskar, R.; Xavier, L.S.E.; Udayakumaran, G.; Kumar, D.S.; Venkatesh, R.; Nagella, P. Biotic elicitors: A boon for the in-vitro production of plant secondary metabolites. Plant Cell Tissue Organ Cult. 2021, 147, 1-18. [CrossRef]

7. Süntar, I.; Çetinkaya, S.; Haydaroğlu, Ü.S.; Habtemariam, S. Bioproduction process of natural products and biopharmaceuticals: Biotechnological aspects. Biotechnol. Adv. 2021, 50, 107768. [CrossRef]

8. Newman, D.J.; Cragg, G.M. Natural products as sources of new drugs over the nearly four decades from 01/1981 to 09/2019. J Nat. Prod. 2020, 83, 770-803. [CrossRef]

9. Ochoa-Villarreal, M.; Howat, S.; Hong, S.; Jang, M.O.; Jin, Y.-W.; Lee, E.-K.; Loake, G.J. Plant cell culture strategies for the production of natural products. BMB Rep. 2016, 49, 149-158. [CrossRef]

10. Süntar, I. Importance of Ethnopharmacological Studies in Drug Discovery: Role of Medicinal Plants. Phytochem. Rev. 2019, 5, 1199-1209. [CrossRef]

11. Georgiev, M.I.; Weber, J.; Maciuk, A. Bioprocessing of plant cell cultures for mass production of targeted compounds. Appl. Microbiol. Biotechnol. 2009, 83, 809-823. [CrossRef]

12. Doran, P.M. Bioreactors, stirred tank for culture of plant cells. Encycl. Ind. Biotechnol. 2010, 1, 1-35. [CrossRef]

13. Ruffoni, B.; Pistelli, L.; Bertoli, A.; Pistelli, L. Plant Cell Cultures: Bioreactors for Industrial Production. Adv. Exp. Med. Biol. 2010, 698, 203-221. [CrossRef] [PubMed]

14. Namdeo, A.G.; Ingawale, D.K. Ashwagandha: Advances in plant biotechnological approaches for propagation and production of bioactive compounds. J. Ethnopharmacol. 2021, 271, 113709. [CrossRef]

15. Kolewe, M.E.; Gaurav, V.; Roberts, S.C. Pharmaceutically active natural product synthesis and supply via plant cell culture technology. Mol. Pharm. 2008, 5, 243-256. [CrossRef]

16. Georgiev, M.I.; Weber, J. Bioreactors for plant cells: Hardware configuration and internal environment optimization as tools for wider commercialization. Biotechnol. Lett. 2014, 36, 1359-1367. [CrossRef]

17. Taroncher, M.; Vila-Donat, P.; Tolosa, J.; Ruiz, M.J.; Rodríguez-Carrasco, Y. Biological activity and toxicity of plant nutraceuticals: An overview. Curr. Opin. Food Sci. 2021, 42, 113-118. [CrossRef]

18. Jamwal, K.; Bhattacharya, S.; Puri, S. Plant growth regulator mediated consequences of secondary metabolites in medicinal plants. J. Appl. Res. Med. Aromat. Plants 2018, 9, 26-38. [CrossRef]

19. Wang, S.; Alseekh, S.; Fernie, A.R.; Luo, J. The structure and function of major plant metabolite modifications. Mol. Plant 2019, 12, 899-919. [CrossRef] [PubMed]

20. Nielsen, E.; Temporiti, M.E.E.; Cella, R. Improvement of phytochemical production by plant cells and organ culture and by genetic engineering. Plant Cell Rep. 2019, 38, 1199-1215. [CrossRef]

21. Verma, N.; Shukla, S. Impact of various factors responsible for fluctuation in plant secondary metabolites. J. Appl. Res. Med. Aromat. Plants 2015, 2, 105-113. [CrossRef]

22. Zhong, J.-J. Plant secondary metabolites. Compr. Biotechnol. 2011, 324-333. [CrossRef] 
23. Sajc, L.; Grubisic, D.; Vunjak-Novakovic, G. Bioreactors for plant engineering: An outlook for further research. Biochem. Eng. J. 2000, 4, 89-99. [CrossRef]

24. Werner, S.; Maschke, R.W.; Eibl, D.; Eibl, R. Bioreactor technology for sustainable production of plant cell-derived products. In Bioprocessing of Plant In Vitro Systems; Springer: Cham, Switzerland, 2018; pp. 413-432. [CrossRef]

25. Casciaro, B.; Mangiardi, L.; Cappiello, F.; Romeo, I.; Loffredo, M.R.; Iazzetti, A.; Calcaterra, A.; Goggiamani, A.; Ghirga, F.; Mangoni, M.L.; et al. Naturally-occurring Alkaloids of plant origin as potential antimicrobials against antibiotic-resistant infections. Molecules 2020, 25, 3619. [CrossRef]

26. Islam, M.T.; Mubarak, M.S. Pyrrolidine alkaloids and their promises in pharmacotherapy. Adv. Tradit. Med. 2020, 20, 13-22. [CrossRef]

27. Tran, N.; Pham, B.; Le, L. Bioactive compounds in anti-diabetic plants: From herbal medicine to modern drug discovery. Biology 2020, 9, 252. [CrossRef]

28. Rodriguez-Garcia, A.; Hosseini, S.; Martinez-Chapa, S.O.; Cordell, G.A. Multi-target activities of selected Alkaloids and Terpenoids. Mini-Rev. Org. Chem. 2017, 14, 272-279. [CrossRef]

29. Shehadeh, M.; Suaifan, G.; Abu-Odeh, A. Plants secondary metabolites as blood glucose-lowering molecules. Molecules 2021, 26, 4333. [CrossRef]

30. Sharifi-Rad, J.; Rajabi, S.; Martorell, M.; López, M.D.; Toro, M.T.; Barollo, S.; Armanini, D.; Fokou, P.V.T.; Zagotto, G.; Ribaudo, G.; et al. Plant natural products with anti-thyroid cancer activity. Fitoterapia 2020, 146, 104640. [CrossRef]

31. Shah, S.M.A.; Akram, M.; Riaz, M.; Munir, N.; Rasool, G. Cardioprotective potential of plant-derived molecules: A scientific and medicinal approach. Dose-Response 2019, 17, 1559325819852243. [CrossRef]

32. Smetanska, I. Sustainable Production of Polyphenols and Antioxidants by Plant In Vitro Cultures; Springer: Berlin/Heidelberg, Germany, 2018; ISBN 9783319545998.

33. Suresh, Y.; Rajasekar, G.; Lavanya, T.; Lakshminarsimhulu, B.; Reddy, K.S.; Reddy, S.R. Antioxidant and antidiabetic properties of isolated fractions from methanolic extract derived from the whole plant of Cleome viscosa L. Future J. Pharm. Sci. 2020, 6, 1-18. [CrossRef]

34. Croft, K.D.; Yamashita, Y.; O’Donoghue, H.; Shirasaya, D.; Ward, N.C.; Ashida, H. Screening plant derived dietary phenolic compounds for bioactivity related to cardiovascular disease. Fitoterapia 2018, 126, 22-28. [CrossRef] [PubMed]

35. Olivares-Vicente, M.; Barrajon-Catalan, E.; Herranz-Lopez, M.; Segura-Carretero, A.; Joven, J.; Encinar, J.A.; Micol, V. Plantderived polyphenols in human health: Biological activity, metabolites and putative molecular targets. Curr. Drug Metab. 2018, 19, 351-369. [CrossRef] [PubMed]

36. Eljounaidi, K.; Lichman, B.R. Nature's chemists: The discovery and engineering of phytochemical biosynthesis. Front. Chem. 2020, 8, 1041. [CrossRef] [PubMed]

37. Jahangeer, M.; Fatima, R.; Ashiq, M.; Basharat, A.; Qamar, S.A.; Bilal, M.; Iqbal, H.M. Therapeutic and biomedical potentialities of terpenoids-A review. J. Pure Appl. Microbiol. 2021, 15, 471-483. [CrossRef]

38. Zaynab, M.; Fatima, M.; Abbas, S.; Sharif, Y.; Umair, M.; Zafar, M.H.; Bahadar, K. Role of secondary metabolites in plant defense against pathogens. Microb. Pathog. 2018, 124, 198-202. [CrossRef]

39. Sonigra, P.; Meena, M. Metabolic profile, bioactivities, and variations in the chemical constituents of essential oils of the ferula genus (Apiaceae). Front. Pharmacol. 2021, 11, 2328. [CrossRef] [PubMed]

40. Blažević, I.; Montaut, S.; Burčul, F.; Olsen, C.E.; Burow, M.; Rollin, P.; Agerbirk, N. Glucosinolate structural diversity, identification, chemical synthesis and metabolism in plants. Phytochemistry 2020, 169, 112100. [CrossRef]

41. Maina, S.; Misinzo, G.; Bakari, G.; Kim, H.-Y. Human, animal and plant health benefits of glucosinolates and strategies for enhanced bioactivity: A systematic review. Molecules 2020, 25, 3682. [CrossRef]

42. Eibl, R.; Meier, P.; Stutz, I.; Schildberger, D.; Hühn, T.; Eibl, D. Plant cell culture technology in the cosmetics and food industries: Current state and future trends. Appl. Microbiol. Biotechnol. 2018, 102, 8661-8675. [CrossRef]

43. Karki, U.; Fang, H.; Guo, W.; Unnold-Cofre, C.; Xu, J. Cellular engineering of plant cells for improved therapeutic protein production. Plant Cell Rep. 2021, 40, 1087-1099. [CrossRef] [PubMed]

44. Narayani, M.; Srivastava, S. Elicitation: A stimulation of stress in in vitro plant cell/tissue cultures for enhancement of secondary metabolite production. Phytochem. Rev. 2017, 16, 1227-1252. [CrossRef]

45. Woo, H.-A.; Ku, S.S.; Jie, E.Y.; Kim, H.; Kim, H.-S.; Cho, H.S.; Jeong, W.-J.; Park, S.U.; Min, S.R.; Kim, S.W. Efficient plant regeneration from embryogenic cell suspension cultures of Euonymus alatus. Sci. Rep. 2021, 11, 15120. [CrossRef]

46. Ali, A.M.A.; El-Nour, M.E.M.; Yagi, S.M. Total phenolic and flavonoid contents and antioxidant activity of ginger (Zingiber officinale Rosc.) rhizome, callus and callus treated with some elicitors. J. Genet. Eng. Biotechnol. 2018, 16, 677-682. [CrossRef] [PubMed]

47. Babich, O.; Sukhikh, S.; Pungin, A.; Ivanova, S.; Asyakina, L.; Prosekov, A. Modern trends in the in vitro production and use of callus, suspension cells and root cultures of medicinal plants. Molecules 2020, 25, 5805. [CrossRef]

48. Furusaki, S.; Takeda, T. Bioreactors for plant cell culture. Compr. Biotechnol. 2017, 519-530. [CrossRef]

49. Niazian, M. Application of genetics and biotechnology for improving medicinal plants. Planta 2019, 249, 953-973. [CrossRef] [PubMed] 
50. Kwon, Y.-W.; Lee, S.-H.; Kim, A.-R.; Kim, B.J.; Park, W.-S.; Hur, J.; Jang, H.; Yang, H.-M.; Cho, H.-J.; Kim, H.-S. Plant callus-derived shikimic acid regenerates human skin through converting human dermal fibroblasts into multipotent skin-derived precursor cells. Stem Cell Res. Ther. 2021, 12, 346. [CrossRef]

51. Gonçalves, S.; Romano, A. Production of plant secondary metabolites by using biotechnological tools. In Secondary Metabolites, Sources and Applications; IntechOpen: London, UK, 2018. [CrossRef]

52. Isah, T.; Umar, S.; Mujib, A.; Sharma, M.P.; Rajasekharan, P.E.; Zafar, N.; Frukh, A. Secondary metabolism of pharmaceuticals in the plant in vitro cultures: Strategies, approaches, and limitations to achieving higher yield. Plant Cell Tissue Organ Cult. 2018, 132, 239-265. [CrossRef]

53. Prasad, G.D.; Sudina, B.; Janardan, L.; Rajani, S.; Rosario, G.-G.M. Establishment of regenerative callus, cell suspension system, and molecular characterization of Taxus wallichiana Zucc. for the in vitro production of Taxol. J. Appl. Pharm. Sci. 2020, 11, 22-34. [CrossRef]

54. Sharma, K.; Zafar, R. Optimization of methyl jasmonate and $\beta$-cyclodextrin for enhanced production of taraxerol and taraxasterol in (Taraxacum officinale Weber) cultures. Plant Physiol. Biochem. 2016, 103, 24-30. [CrossRef] [PubMed]

55. Chastang, T.; Pozzobon, V.; Taidi, B.; Courot, E.; Clément, C.; Pareau, D. Resveratrol production by grapevine cells in fed-batch bioreactor: Experiments and modelling. Biochem. Eng. J. 2018, 131, 9-16. [CrossRef]

56. Jeong, Y.J.; Park, S.H.; Park, S.-C.; Kim, S.; Kim, T.H.; Lee, J.; Kim, S.W.; Ryu, Y.B.; Jeong, J.C.; Kim, C.Y. Induced extracellular production of stilbenes in grapevine cell culture medium by elicitation with methyl jasmonate and stevioside. Bioresour. Bioprocess. 2020, 7, 40643. [CrossRef]

57. Le, K.-C.; Jeong, C.-S.; Lee, H.; Paek, K.-Y.; Park, S.-Y. Ginsenoside accumulation profiles in long- and short-term cell suspension and adventitious root cultures in Panax ginseng. Hortic. Environ. Biotechnol. 2018, 60, 125-134. [CrossRef]

58. Malik, S.; Cusido, R.M.; Mirjalili, M.H.; Moyano, E.; Palazon, J.; Bonfill, M. Production of the anticancer drug taxol in Taxus baccata suspension cultures: A review. Process. Biochem. 2011, 46, 23-34. [CrossRef]

59. Sahakyan, N.; Petrosyan, M.; Trchounian, A. The activity of Alkanna species in vitro culture and intact plant extracts against antibiotic resistant bacteria. Curr. Pharm. Des. 2019, 25, 1861-1865. [CrossRef]

60. Gwon, S.Y.; Ahn, J.; Jung, C.H.; Moon, B.; Ha, T.-Y. Shikonin attenuates hepatic steatosis by enhancing beta oxidation and energy expenditure via AMPK activation. Nutrients 2020, 12, 1133. [CrossRef]

61. Jeziorek, M.; Damianakos, H.; Kawiak, A.; Laudy, A.E.; Zakrzewska, K.; Sykłowska-Baranek, K.; Chinou, I.; Pietrosiuk, A. Bioactive rinderol and cynoglosol isolated from Cynoglossum columnae Ten. in vitro root culture. Ind. Crop. Prod. 2019, 137, 446-452. [CrossRef]

62. Rat, A.; Naranjo, H.D.; Krigas, N.; Grigoriadou, K.; Maloupa, E.; Alonso, A.V.; Schneider, C.; Papageorgiou, V.P.; Assimopoulou, A.N.; Tsafantakis, N.; et al. Endophytic bacteria from the roots of the medicinal plant Alkanna tinctoria Tausch (Boraginaceae): Exploration of plant growth promoting properties and potential role in the production of plant secondary metabolites. Front. Microbiol. 2021, 12, 113. [CrossRef] [PubMed]

63. Fu, J.-Y.; Zhao, H.; Bao, J.-X.; Wen, Z.-L.; Fang, R.-J.; Fazal, A.; Yang, M.-K.; Liu, B.; Yin, T.-M.; Pang, Y.-J.; et al. Establishment of the hairy root culture of Echium plantagineum L. and its shikonin production. 3 Biotech 2020, 10, 429. [CrossRef]

64. Baque, A.; Shiragi, H.K.; Moh, S.-H.; Lee, E.-J.; Paek, K.-Y. Production of biomass and bioactive compounds by adventitious root suspension cultures of Morinda citrifolia (L.) in a liquid-phase airlift balloon-type bioreactor. Vitr. Cell. Dev. Biol. Anim. 2013, 49, 737-749. [CrossRef]

65. Veremeichik, G.; Bulgakov, V.; Shkryl, Y.; Silantieva, S.; Makhazen, D.; Tchernoded, G.; Mischenko, N.; Fedoreyev, S.; Vasileva, E. Activation of anthraquinone biosynthesis in long-cultured callus culture of Rubia cordifolia transformed with the rolA plant oncogene. J. Biotechnol. 2019, 306, 38-46. [CrossRef] [PubMed]

66. Mariadoss, A.; Satdive, R.; Fulzele, D.P.; Ramamoorthy, S.; Zayed, H.; Younes, S.; Rajasekaran, C. Enhanced production of anthraquinones by gamma-irradiated cell cultures of Rubia cordifolia in a bioreactor. Ind. Crop. Prod. 2020, 145, 111987. [CrossRef]

67. Kowalczyk, T.; Sitarek, P.; Toma, M.; Rijo, P.; Domínguez-Martíne, E.; Falcó, I.; Sánchez, G.; Śliwiński, T. Enhanced accumulation of betulinic acid in transgenic hairy roots of Senna obtusifolia growing in the Sprinkle Bioreactor and evaluation of their biological properties in various biological models. Chem. Biodivers. 2021, 18, e2100455. [CrossRef] [PubMed]

68. Açıköz, M.A. Effects of sorbitol on the production of phenolic compounds and terpenoids in the cell suspension cultures of Ocimum basilicum L. Biologia 2021, 76, 395-409. [CrossRef]

69. Pandey, P.; Singh, S.; Banerjee, S. Ocimum basilicum suspension culture as resource for bioactive triterpenoids: Yield enrichment by elicitation and bioreactor cultivation. Plant Cell Tissue Organ Cult. 2019, 137, 65-75. [CrossRef]

70. Li, Y.-P.; Tang, D.-B.; Wang, X.-Q.; Wang, M.; Zhang, Q.-F.; Liu, Y.; Shen, B.-Y.; Chen, J.-G.; Yin, Z.-P. Development of Origanum vulgare cell suspension culture to produce polyphenols and the stimulation effect of salicylic acid elicitation and phenylalanine feeding. Biotechnol. Bioprocess Eng. 2021, 26, 456-467. [CrossRef]

71. Gonçalves, S.; Moreira, E.; Grosso, C.; Andrade, P.B.; Valentão, P.; Romano, A. Phenolic profile, antioxidant activity and enzyme inhibitory activities of extracts from aromatic plants used in Mediterranean diet. J. Food Sci. Technol. 2017, 54, 219-227. [CrossRef]

72. Sahraroo, A.; Mirjalili, M.H.; Corchete, P.; Babalar, M.; Moghadam, M.R.F. Establishment and characterization of a Satureja khuzistanica Jamzad (Lamiaceae) cell suspension culture: A new in vitro source of rosmarinic acid. Cytotechnology 2016, 68, 1415-1424. [CrossRef] 
73. Sahraroo, A.; Mirjalili, M.H.; Babalar, M.; Zarei, A. Enhancement of rosmarinic acid production by Satureja khuzistanica cell suspensions: Effects of phenylalanine and sucrose. SABRAO J. Breed. Genet. 2018, 50, 25-35.

74. Och, A.; Podgórski, R.; Nowak, R. Biological activity of berberine-A summary update. Toxins 2020, 12, 713. [CrossRef]

75. Khan, T.; Krupadanam, D.; Anwar, S.Y. The role of phytohormone on the production of berberine in the calli cultures of an endangered medicinal plant, turmeric (Coscinium fenestratum L.). Afr. J. Biotechnol. 2008, 7, 3244-3246. [CrossRef]

76. Yamada, Y.; Yoshimoto, T.; Yoshida, S.T.; Sato, F. Characterization of the promoter region of biosynthetic enzyme genes involved in Berberine Biosynthesis in Coptis japonica. Front. Plant Sci. 2016, 7, 1352. [CrossRef]

77. Cheung, C.K.-L.; Leksawasdi, N.; Doran, P.M. Bioreactor scale-down studies of suspended plant cell cultures. AIChE J. 2018, 64, 4281-4288. [CrossRef]

78. Tabata, M. Transport and secretion of natural products in plant cell cultures. Planta Med. 1991, 57, S21-S26. [CrossRef]

79. Sato, F.; Yamada, Y. High berberine-producing cultures of coptis japonica cells. Phytochemistry 1984, 23, 281-285. [CrossRef]

80. Hou, M.; Wang, R.; Zhao, S.; Wang, Z. Ginsenosides in Panax genus and their biosynthesis. Acta Pharm. Sin. B 2021, 11, 1813-1834. [CrossRef] [PubMed]

81. Adil, M.; Jeong, B.R. In vitro cultivation of Panax ginseng C.A. Meyer. Ind. Crop. Prod. 2018, 122, 239-251. [CrossRef]

82. Nazir, R.; Kumar, V.; Gupta, S.; Dwivedi, P.; Pandey, D.K.; Dey, A. Biotechnological strategies for the sustainable production of diosgenin from Dioscorea spp. Appl. Microbiol. Biotechnol. 2021, 105, 569-585. [CrossRef] [PubMed]

83. Shaikh, S.; Shriram, V.; Khare, T.; Kumar, V. Biotic elicitors enhance diosgenin production in Helicteres isora L. suspension cultures via up-regulation of CAS and HMGR genes. Physiol. Mol. Biol. Plants 2020, 26, 593-604. [CrossRef]

84. Deshpande, H.A.; Bhalsing, S.R. Isolation and characterization of diosgenin from in vitro cultured tissues of Helicteres isora L. Physiol. Mol. Biol. Plants 2013, 20, 89-94. [CrossRef]

85. Das, A.; Sarkar, S.; Bhattacharyya, S.; Gantait, S. Biotechnological advancements in Catharanthus roseus (L.) G. Don. Appl. Microbiol. Biotechnol. 2020, 104, 4811-4835. [CrossRef]

86. Thakore, D.; Srivastava, A.; Sinha, A.K. Mass production of Ajmalicine by bioreactor cultivation of hairy roots of Catharanthus roseus. Biochem. Eng. J. 2017, 119, 84-91. [CrossRef]

87. Alamgir, A.N.M. Cultivation of herbal drugs, biotechnology, and in vitro production of secondary metabolites, high-value medicinal plants, herbal wealth, and herbal trade. In Therapeutic Use of Medicinal Plants and Their Extracts: Volume 1; Springer: Berlin/Heidelberg, Germany, 2017; pp. 379-452, ISBN 9783319638621.

88. Changxing, L.; Galani, S.; Hassan, F.-U.; Rashid, Z.; Naveed, M.; Fang, D.; Ashraf, A.; Qi, W.; Arif, A.; Saeed, M.; et al. Biotechnological approaches to the production of plant-derived promising anticancer agents: An update and overview. Biomed. Pharmacother. 2020, 132, 110918. [CrossRef] [PubMed]

89. Kumar, P.; Sharma, P.; Kumar, V.; Kumar, A. Plant resources: In vitro production, challenges and prospects of secondary Metabolites from medicinal plants. Ind. Biotechnol. 2019, 2019, 89-104. [CrossRef]

90. Salehi, M.; Karimzadeh, G.; Naghavi, M.R. Synergistic effect of coronatine and sorbitol on artemisinin production in cell suspension culture of Artemisia annua L. cv. Anamed. Plant Cell Tissue Organ Cult. 2019, 137, 587-597. [CrossRef]

91. Kayani, W.K.; Kiani, B.H.; Dilshad, E.; Mirza, B. Biotechnological approaches for artemisinin production in Artemisia. World J. Microbiol. Biotechnol. 2018, 34, 54. [CrossRef] [PubMed]

92. Kubica, P.; Szopa, A.; Kokotkiewicz, A.; Miceli, N.; Taviano, M.; Maugeri, A.; Cirmi, S.; Synowiec, A.; Gniewosz, M.; Elansary, H.; et al. Production of Verbascoside, Isoverbascoside and Phenolic acids in callus, suspension, and bioreactor cultures of Verbena officinalis and biological properties of biomass extracts. Molecules 2020, 25, 5609. [CrossRef]

93. Yue, W.; Ming, Q.-L.; Lin, B.; Rahman, K.; Zheng, C.-J.; Han, T.; Qin, L.-P. Medicinal plant cell suspension cultures: Pharmaceutical applications and high-yielding strategies for the desired secondary metabolites. Crit. Rev. Biotechnol. 2016, 36, 215-232. [CrossRef]

94. Valdiani, A.; Hansen, O.K.; Nielsen, U.B.; Johannsen, V.K.; Shariat, M.; Georgiev, M.I.; Omidvar, V.; Ebrahimi, M.; Dinanai, E.T.; Abiri, R. Bioreactor-based advances in plant tissue and cell culture: Challenges and prospects. Crit. Rev. Biotechnol. 2018, 39, 20-34. [CrossRef]

95. Thakur, M.; Bhattacharya, S.; Khosla, P.K.; Puri, S. Improving production of plant secondary metabolites through biotic and abiotic elicitation. J. Appl. Res. Med. Aromat. Plants 2019, 12,1-12. [CrossRef]

96. Nabi, N.; Singh, S.; Saffeullah, P. Responses of in vitro cell cultures to elicitation: Regulatory role of jasmonic acid and methyl jasmonate: A review. Vitr. Cell. Dev. Biol. Anim. 2021, 57, 341-355. [CrossRef]

97. Khan, T.; Khan, T.; Hano, C.; Abbasi, B.H. Effects of chitosan and salicylic acid on the production of pharmacologically attractive secondary metabolites in callus cultures of Fagonia indica. Ind. Crop. Prod. 2019, 129, 525-535. [CrossRef]

98. Kehie, M.; Kumaria, S.; Tandon, P. Biotechnological enhancement of capsaicin biosynthesis in cell suspension cultures of Naga King Chili (Capsicum chinense Jacq.). Bioprocess Biosyst. Eng. 2016, 39, 205-210. [CrossRef]

99. Schenke, D.; Utami, H.P.; Zhou, Z.; Gallegos, M.-T.; Cai, D. Suppression of UV-B stress induced flavonoids by biotic stress: Is there reciprocal crosstalk? Plant Physiol. Biochem. 2019, 134, 53-63. [CrossRef]

100. Lange, B.M. Commercial-scale tissue culture for the production of plant natural products: Successes, failures and outlook. In Biotechnology of Natural Products; Springer: Cham, Switzerland, 2018; pp. 189-218. [CrossRef]

101. Marketwatch. Available online: https:/ /www.marketwatch.com/press-release/paclitaxel-market-size-in-2021-87-cagr-withtop-countries-data-competition-strategies-share-industry-analysis-by-top-manufactures-growth-insights-and-forecasts-to-20 26-2021-08-06 (accessed on 8 December 2021). 
102. Frense, D. Taxanes: Perspectives for biotechnological production. Appl. Microbiol. Biotechnol. 2007, 73, 1233-1240. [CrossRef]

103. Espinosa-Leal, C.A.; Puente-Garza, C.A.; García-Lara, S. In vitro plant tissue culture: Means for production of biological active compounds. Planta 2018, 248, 1-18. [CrossRef] [PubMed]

104. Wagner, H.; Stuppner, H.; Schäfer, W.; Zenk, M. Immunologically active polysaccharides of Echinacea purpurea cell cultures. Phytochemistry 1988, 27, 119-126. [CrossRef]

105. DiCosmo, F.; Misawa, M. Plant cell and tissue culture: Alternatives for metabolite production. Biotechnol. Adv. 1995, 13, 425-453. [CrossRef]

106. Giri, A.; Narasu, M.L. Production of podophyllotoxin from Podophyllum hexandrum: A potential natural product for clinically useful anticancer drugs. Cytotechnology 2000, 34, 17-26. [CrossRef]

107. Sasheva, P.; Ionkova, I. Small Cells for Big Ideas: The Cytotoxic Podophyllotoxin and the Long Journey in Discovering Its Biosynthetic Pathway. In Biotechnology and Production of Anti-Cancer Compounds; Federal University of Maranhao: Sao Luis, Brazil, 2017. [CrossRef]

108. Rao, K.; Chodisetti, B.; Gandi, S.; Giri, A.; Kishor, P.B.K. Cadmium chloride elicitation of Abutilon indicum cell suspension cultures for enhanced stigmasterol production. Plant Biosyst. Int. J. Deal. All Asp. Plant Biol. 2021, 155, 1-6. [CrossRef]

109. Ojha, T.; Hu, Q.; Colombo, C.; Wit, J.; van Geijn, M.; van Steenbergen, M.J.; Bagheri, M.; Königs-Werner, H.; Buhl, E.M.; Bansal, R.; et al. Lyophilization stabilizes clinical-stage core-crosslinked polymeric micelles to overcome cold chain supply challenges. Biotechnol. J. 2021, 16, 2000212. [CrossRef] [PubMed]

110. McElroy, C.; Jennewein, S. Taxol ${ }^{\circledR}$ biosynthesis and production: From forests to fermenters. In Biotechnology of Natural Products; Springer: Berlin/Heidelberg, Germany, 2017; pp. 145-185.

111. Chattopadhyay, S.; Farkya, S.; Srivastava, A.; Bisaria, V.S. Bioprocess considerations for production of secondary metabolites by plant cell suspension cultures. Biotechnol. Bioprocess Eng. 2002, 7, 138-149. [CrossRef]

112. Lee, S.-W.; Kim, Y.-M.; Cho, C.H.; Kim, Y.T.; Kim, S.M.; Hur, S.Y.; Kim, J.-H.; Kim, B.-G.; Kim, S.-C.; Ryu, H.-S.; et al. An open-label, randomized, parallel, phase ii trial to evaluate the efficacy and safety of a cremophor-free polymeric micelle formulation of paclitaxel as first-line treatment for ovarian cancer: A Korean gynecologic oncology group study (KGOG-3021). Cancer Res. Treat. 2018, 50, 195-203. [CrossRef] [PubMed]

113. Muranaka, T.; Ohkawa, H.; Yamada, Y. Continuous production of scopolamine by a culture of Duboisia leichhardtii hairy root clone in a bioreactor system. Appl. Microbiol. Biotechnol. 1993, 40, 219-223. [CrossRef]

114. D'Amelia, V.; Docimo, T.; Crocoll, C.; Rigano, M. Specialized metabolites and valuable molecules in crop and medicinal plants: The evolution of their use and strategies for their production. Genes 2021, 12, 936. [CrossRef]

115. Singh, J.; Kaushik, N.; Biswas, S. Bioreactors-Technology \& design analysis. Scitech J. 2014, 1, $28-36$.

116. Esperança, M.N.; Mendes, C.E.; Rodriguez, G.Y.; Cerri, M.O.; Béttega, R.; Badino, A.C. Sparger design as key parameter to define shear conditions in pneumatic bioreactors. Biochem. Eng. J. 2020, 157, 107529. [CrossRef]

117. Barragán, L.P.; Figueroa, J.; Durán, L.R.; González, C.A.; Hennigs, C. Fermentative Production Methods; Elsevier: Amsterdam, The Netherlands, 2016; pp. 189-217.

118. Zhang, T.; We, C.; Ren, Y.; Feng, C.; Wu, H. Advances in airlift reactors: Modified design and optimization of operation conditions. Rev. Chem. Eng. 2017, 33, 163-182. [CrossRef]

119. Kumar, N.; Gupta, R.; Bansal, A. Effect of surface tension on hydrodynamics and mass transfer coefficient in airlift reactors. Chem. Eng. Technol. 2020, 43, 995-1004. [CrossRef]

120. Tervasmäki, P.; Latva-Kokko, M.; Taskila, S.; Tanskanen, J. Effect of oxygen transfer on yeast growth-Growth kinetic and reactor model to estimate scale-up effects in bioreactors. Food Bioprod. Process. 2018, 111, 129-140. [CrossRef]

121. Fitzpatrick, J.J. Insights from mathematical modelling into energy requirement and process design of continuous and batch stirred tank aerobic bioreactors. ChemEngineering 2019, 3, 65. [CrossRef]

122. Ahmadi-Sakha, S.; Sharifi, M.; Niknam, V. Bioproduction of phenylethanoid glycosides by plant cell culture of Scrophularia striata Boiss.: From shake-flasks to bioreactor. Plant Cell Tissue Organ Cult. 2016, 124, 275-281. [CrossRef]

123. Estrada-Zúñiga, M.E.; Cruz-Sosa, F.; Rodriguez-Monroy, M.; Verde-Calvo, J.R.; Vernon-Carter, E.J. Phenylpropanoid production in callus and cell suspension cultures of Buddleja cordata Kunth. Plant Cell Tissue Organ Cult. 2009, 97, 39-47. [CrossRef]

124. Vazquez-Marquez, A.M.; Zepeda-Gómez, C.; Burrola-Aguilar, C.; Bernabé-Antonio, A.; Nieto-Trujillo, A.; Cruz-Sosa, F.; Rodríguez-Monroy, M.; Estrada-Zúñiga, M.E. Effect of stirring speed on the production of phenolic secondary metabolites and growth of Buddleja cordata cells cultured in mechanically agitated bioreactor. Plant Cell Tissue Organ Cult. 2019, 139, 155-166. [CrossRef]

125. Busto, V.; Rodriguez-Talou, J.; Giulietti, A.; Merchuk, J. Effect of shear stress on Anthraquinones production by Rubia tinctorum suspension cultures. Biotechnol. Prog. 2008, 24, 175-181. [CrossRef]

126. Gupta, K.; Garg, S.; Singh, J.; Kumar, M. Enhanced production of napthoquinone metabolite (shikonin) from cell suspension culture of Arnebia sp. and its up-scaling through bioreactor. 3 Biotech 2014, 4, 263-273. [CrossRef]

127. Khojasteh, A.; Mirjalili, M.H.; Palazon, J.; Eibl, R.; Cusido, R.M. Methyl jasmonate enhanced production of rosmarinic acid in cell cultures of Satureja khuzistanicain a bioreactor. Eng. Life Sci. 2016, 16, 740-749. [CrossRef]

128. Lambert, C.; Lemaire, J.; Auger, H.; Guilleret, A.; Reynaud, R.; Clément, C.; Courot, E.; Taidi, B. Optimize, modulate, and scale-up resveratrol and resveratrol dimers bioproduction in Vitis labrusca L. Cell suspension from Flasks to 20 L Bioreactor. Plants 2019, 8, 567. [CrossRef] 
129. Rani, A.; Meghana, R.; Kush, A. Squalene production in the cell suspension cultures of Indian sandalwood (Santalum album L.) in shake flasks and air lift bioreactor. Plant Cell Tissue Organ Cult. 2018, 135, 155-167. [CrossRef]

130. Salehi, M.; Farhadi, S.; Moieni, A.; Safaie, N.; Ahmadi, H. Mathematical modeling of growth and paclitaxel biosynthesis in Corylus avellana cell culture responding to fungal elicitors using multilayer perceptron-genetic algorithm. Front. Plant Sci. 2020, 11, 1148. [CrossRef]

131. Maschke, R.; Geipel, K.; Bley, T. Modeling of plant in vitro cultures: Overview and estimation of biotechnological processes. Biotechnol. Bioeng. 2014, 112, 1-12. [CrossRef] [PubMed]

132. Villegas, A.; Arias, J.P.; Aragón, D.; Ochoa, S.; Arias, M. Structured model and parameter estimation in plant cell cultures of Thevetia peruviana. Bioprocess Biosyst. Eng. 2016, 40, 573-587. [CrossRef]

133. Chattopadhyay, S.; Bisaria, V.S.; Srivastava, A.K. Enhanced production of Podophyllotoxin by Podophyllum hexandrum using in situ cell retention bioreactor. Biotechnol. Prog. 2003, 19, 1026-1028. [CrossRef] [PubMed]

134. Prakash, G.; Srivastava, A.K. Modeling of azadirachtin production by Azadirachta indica and its use for feed forward optimization studies. Biochem. Eng. J. 2006, 29, 62-68. [CrossRef]

135. Amdoun, R.; Khelifi, L.; Khelifi-Slaoui, M.; Amroune, S.; Benyoussef, E.-H.; Thi, D.V.; Assaf-Ducrocq, C.; Gontier, E. Influence of minerals and elicitation on Datura stramonium L. tropane alkaloid production: Modelization of the in vitro biochemical response. Plant Sci. 2009, 177, 81-87. [CrossRef]

136. Thakore, D.; Srivastava, A.K.; Sinha, A.K. Model based fed batch cultivation and elicitation for the overproduction of ajmalicine from hairy roots of Catharanthus roseus. Biochem. Eng. J. 2015, 97, 73-80. [CrossRef]

137. Salehi, M.; Farhadi, S.; Moieni, A.; Safaie, N.; Hesami, M. A hybrid model based on general regression neural network and fruit fly optimization algorithm for forecasting and optimizing paclitaxel biosynthesis in Corylus avellana cell culture. Plant Methods 2021, 17, 13. [CrossRef]

138. Villadsen, J.; Nielsen, J.; Lidén, G. Chemicals from metabolic pathways. In Bioreaction Engineering Principles; Springer: Boston, MA, USA, 2011; pp. 7-62. ISBN 97814419968792.

139. Melgarejo-Torres, R.; Castillo-Araiza, C.O.; López-Ordaz, P.; Torres-Martínez, D.; Gutiérrez-Rojas, M.; Lye, G.; Huerta-Ochoa, S. Kinetic mathematical model for ketone bioconversion using Escherichia coli TOP10 pQR239. Chem. Eng. J. 2014, 240, 1-9. [CrossRef]

140. Palmerín-Carreño, D.; Castillo-Araiza, C.; Rutiaga-Quiñones, O.; Verde-Calvo, J.; Huerta-Ochoa, S. Kinetic, oxygen mass transfer and hydrodynamic studies in a three-phase stirred tank bioreactor for the bioconversion of (+)-valencene on Yarrowia lipolytica 2.2ab. Biochem. Eng. J. 2016, 113, 37-46. [CrossRef]

141. Castillo-Araiza, C.; Palmerín-Carreño, D.; Prado-Barragán, A.; Huerta-Ochoa, S. On the conceptual design of a partitioning technology for the bioconversion of (+)-valencene to (+)-nootkatone on whole cells: Experimentation and modelling. Chem. Eng. Process. Process. Intensif. 2017, 122, 493-507. [CrossRef]

142. Liu, Y. A simple thermodynamic approach for derivation of a general Monod equation for microbial growth. Biochem. Eng. J. 2006, 31, 102-105. [CrossRef]

143. Liu, Y. Overview of some theoretical approaches for derivation of the Monod equation. Appl. Microbiol. Biotechnol. 2007, 73, 1241-1250. [CrossRef]

144. Wang, J.D.; Levin, P.A. Metabolism, cell growth and the bacterial cell cycle. Nat. Rev. Genet. 2009, 7, 822-827. [CrossRef]

145. Henson, A.M. Dynamic modeling of microbial cell populations. Curr. Opin. Biotechnol. 2003, 14, 460-467. [CrossRef]

146. Daugulis, A.J. Partitioning bioreactors. Curr. Opin. Biotechnol. 1997, 8, 169-174. [CrossRef]

147. Kalil, S.; Maugeri, F.; Rodrigues, M. Response surface analysis and simulation as a tool for bioprocess design and optimization. Process. Biochem. 2000, 35, 539-550. [CrossRef]

148. Ríos-Morales, D.; Castillo-Araiza, C.O.; Vizcarra-Mendoza, M.G. Study of the agglomeration mechanism of a natural organic solid in a bench-scale wet fluidized bed using statistical analysis and discretized population balance. Chem. Eng. Commun. 2014, 201, 23-40. [CrossRef]

149. Khuri, A.I.; Mukhopadhyay, S. Response surface methodology. Wiley Interdiscip. Rev. Comput. Stat. 2010, 2, 128-149. [CrossRef]

150. Dellino, G.; Kleijnen, J.P.; Meloni, C. Robust optimization in simulation: Taguchi and response surface methodology. Int. J. Prod. Econ. 2010, 125, 52-59. [CrossRef]

151. Anderson-Cook, C.M.; Borror, C.M.; Montgomery, D.C. Response surface design evaluation and comparison. J. Stat. Plan. Inference 2009, 139, 629-641. [CrossRef]

152. Montgomery, D.C. Design and Analysis of Experiments; John Wiley: Hoboken, NJ, USA, 2013; ISBN 9781118146927.

153. Box, G. JS hunter, WG hunter. Stat. Exp. Des. Innov. Discov. 2005, 21, 303-304. [CrossRef]

154. Hanrahan, G.; Lu, K. Application of factorial and response surface methodology in modern experimental design and optimization. Crit. Rev. Anal. Chem. 2006, 36, 141-151. [CrossRef]

155. Malik, S.; Bhushan, S.; Sharma, M.; Ahuja, P.S. Physico-chemical factors influencing the shikonin derivatives production in cell suspension cultures of Arnebia euchroma (Royle) Johnston, a medicinally important plant species. Cell Biol. Int. 2011, 35, 153-158. [CrossRef] [PubMed]

156. Nartop, P. Engineering of biomass accumulation and secondary metabolite production in plant cell and tissue cultures. In Plant Metabolites and Regulation under Environmental Stress; Academic Press: Cambridge, MA, USA, 2018; pp. 169-194. [CrossRef] 
157. Ten Hoopen, H.J.G.; Vinke, J.L.; Moreno, P.; Verpoorte, R.; Heijnen, J.J. Influence of temperature on growth and ajmalicine production by Catharantus roseus suspension cultures. Enzym. Microb. Technol. 2002, 30, 56-65. [CrossRef]

158. Georgiev, M.; Pavlov, A.; Ilieva, M. Rosmarinic acid production by Lavandula vera MM cell suspension: The effect of temperature. Biotechnol. Lett. 2004, 26, 855-856. [CrossRef] [PubMed]

159. Ali, M.; Abbasi, B.H. Light-induced fluctuations in biomass accumulation, secondary metabolites production and antioxidant activity in cell suspension cultures of Artemisia absinthium L. J. Photochem. Photobiol. B Biol. 2014, 140, 223-227. [CrossRef]

160. Beigmohamadi, M.; Movafeghi, A.; Sharafi, A.; Jafari, S.; Danafar, H.; Beigmohammadi, M. Cell suspension culture of Plumbago europaea L. Towards production of Plumbagin. Iran. J. Biotechnol. 2019, 17, 46-54. [CrossRef] [PubMed]

161. Gallego, A.M.; Rojas, L.F.; Valencia, W.G.; Atehortúa, L.; Urrea, A.I.; Fister, A.S.; Guiltinan, M.J.; Maximova, S.N.; Pabón-Mora, N. Transcriptomic analyses of cacao flavonoids produced in photobioreactors. BMC Genom. 2021, 22, 551. [CrossRef]

162. Bong, F.J.; Subramaniam, S.; Chew, B.L. Effects of light illumination and subculture frequency on biomass production in cell suspension cultures of Clinacanthus nutans. Malays. Appl. Biol. 2021, 50, 197-204.

163. Zavala-Ortiz, D.; Veracruz, T.N.; Martínez-Montero, M.; Guedon, E.; Marc, A.; Ebel, B.; Barradas-Dermitz, D.; Hayward-Jones, P.; Mata-Rosas, M.; Aguilar-Uscanga, M. Interest of cellular differentiation in the production of vincristine and vinblastine in suspension cultures of Catharanthus roseus (L.) G Don. Rev. Mex. Ing. Química 2021, 20, 807-821. [CrossRef]

164. Andi, S.A.; Gholami, M.; Ford, C.M.; Maskani, F. Impact of light irradiance on the biosynthesis of ABA-elicited phenolic compounds in suspension-cultured Vitis vinifera L. cells. Plant Cell Tissue Organ Cult. 2021, 146, 387-400. [CrossRef]

165. Ali, H.; Khan, M.A.; Ullah, N.; Khan, R.S. Impacts of hormonal elicitors and photoperiod regimes on elicitation of bioactive secondary volatiles in cell cultures of Ajuga bracteosa. J. Photochem. Photobiol. B Biol. 2018, 183, 242-250. [CrossRef]

166. Sharifi, Y.; Omran, V.G.; Ghavami, T.S.T.; Gharakhili, A.N.; Ebrahimzadeh, M.A. Effect of Salicylic acid on Phenols and flavonoids content and DPPH scavenging activity in cell suspension culture of Iranian sodab (Ruta graveolens). Tabari Biomed. Stud. Res. J. 2020, 1, 18-21. [CrossRef]

167. Khoo, H.E.; Azlan, A.; Tang, S.T.; Lim, S.M. Anthocyanidins and anthocyanins: Colored pigments as food, pharmaceutical ingredients, and the potential health benefits. Food Nutr. Res. 2017, 61, 1361779. [CrossRef]

168. Zhou, H.; Purdie, J.; Wang, T.; Ouyang, A. $\mathrm{pH}$ measurement and a rational and practical $\mathrm{pH}$ control strategy for high throughput cell culture system. Biotechnol. Prog. 2009, 26, 872-880. [CrossRef]

169. Riet, K.; van der Lans, R. Mixing in Bioreactor Vessels; Elsevier: Amsterdam, The Netherlands, 2011; pp. 63-80.

170. Garcia-Ochoa, F.; Gomez, E.; Santos, V.E. Fluid dynamic conditions and oxygen availability effects on microbial cultures in STBR: An overview. Biochem. Eng. J. 2020, 164, 107803. [CrossRef]

171. Garcia-Ochoa, F.; Gomez, E. Bioreactor scale-up and oxygen transfer rate in microbial processes: An overview. Biotechnol. Adv. 2009, 27, 153-176. [CrossRef] [PubMed]

172. Thomas, J.A.; Liu, X.; DeVincentis, B.; Hua, H.; Yao, G.; Borys, M.C.; Aron, K.; Pendse, G. A mechanistic approach for predicting mass transfer in bioreactors. Chem. Eng. Sci. 2021, 237, 116538. [CrossRef]

173. Yela, A.C.A.; Chiquiza-Montaño, L.N.; Hoyos, R.; Orozco-Sánchez, F. Rheology and mixing analysis of plant cell cultures (Azadirachta indica, Borojoa patinoi and Thevetia peruviana) in shake flasks. Biochem. Eng. J. 2016, 114, 18-25. [CrossRef]

174. Khandy, M.T.; Kochkin, D.V.; Tomilova, S.V.; Klyushin, A.G.; Galishev, B.A.; Nosov, A.M. Growth and biosynthetic characteristics of Phlojodicarpus sibiricus cell suspension cultures. Russ. J. Plant Physiol. 2021, 68, 569-578. [CrossRef]

175. Tomilova, S.V.; Khandy, M.T.; Kochkin, D.V.; Galishev, B.A.; Klyushin, A.G.; Nosov, A.M. Effect of Synthetic Auxin analogs (2.4-D and $\alpha$-NAA) on growth and biosynthetic characteristics of suspension cell culture of Tribulus terrestris L. Russ. J. Plant Physiol. 2020, 67, 636-645. [CrossRef]

176. Gaid, M.; Wucherpfennig, T.; Scholl, S.; Krull, R. Challenges for the Cultivation of Plant Cells on the Example of Hypericum Perforatum and Taxus Chinensis. Ref. Ser. Phytochem. 2016. [CrossRef]

177. Wilson, A.S.; Cummings, E.M.; Roberts, S.C. Multi-scale engineering of plant cell cultures for promotion of specialized metabolism. Curr. Opin. Biotechnol. 2014, 29, 163-170. [CrossRef]

178. Kolewe, M.E.; Henson, M.A.; Roberts, S.C. Analysis of aggregate size as a process variable affecting paclitaxel accumulation in Taxus suspension cultures. Biotechnol. Prog. 2011, 27, 1365-1372. [CrossRef] [PubMed]

179. Satdive, R.K.; Shinde, A.N.; Singh, S.K.; Kamble, S.; Singh, S.; Malpathak, N.; Fulzele, D.P. Aggregate cell suspension cultures of Psoralea corylifolia improved phytoestrogens production. Biotechnol. Bioprocess Eng. 2015, 20, 373-379. [CrossRef]

180. Kieran, P.M.; Malone, D.M.; MacLoughlin, P.F. Effects of hydrodynamic and interfacial forces on plant cell suspension systems. Mol. Biominer. 2000, 67, 139-177. [CrossRef]

181. Wilson, S.A.; Maindarkar, S.N.; McKee, M.C.; Vilkhovoy, M.; Henson, M.A.; Roberts, S.C. A population balance model to modulate shear for the control of aggregation in Taxus suspension cultures. Biotechnol. Prog. 2020, 36, e2932. [CrossRef] [PubMed]

182. Titova, M.; Popova, E.; Konstantinova, S.; Kochkin, D.; Ivanov, I.; Klyushin, A.; Titova, E.; Nebera, E.; Vasilevskaya, E.; Tolmacheva, G.; et al. Suspension cell culture of Dioscorea deltoidea-A renewable source of biomass and Furostanol Glycosides for food and pharmaceutical industry. Agronomy 2021, 11, 394. [CrossRef]

183. Maischberger, T. Optimized process and bioreactor characterization. Chem. Ing. Tech. 2019, 91, 1719-1723. [CrossRef]

184. Yasin, M.; Jang, N.; Lee, M.; Kang, H.; Aslam, M.; Bazmi, A.A.; Chang, I.S. Bioreactors, gas delivery systems and supporting technologies for microbial synthesis gas conversion process. Bioresour. Technol. Rep. 2019, 7, 100207. [CrossRef] 
185. Huang, T.-K.; McDonald, K.A. Bioreactor engineering for recombinant protein production in plant cell suspension cultures. Biochem. Eng. J. 2009, 45, 168-184. [CrossRef]

186. Martínez-Corona, J.I.; Cisneros-Garza, R.R.; Robledo-Padilla, F.; Parra, R.; Treviño-Martínez, A.S.; Alvarez, A.J. Optical approach for measuring oxygen mass transfer in stirred Tank Bioreactors. Int. J. Chem. React. Eng. 2017, 15, 15. [CrossRef]

187. Salazar-Magallón, J.A.; De La Peña, A.H. Production of antifungal saponins in an airlift bioreactor with a cell line transformed from Solanum chrysotrichum and its activity against strawberry phytopathogens. Prep. Biochem. Biotechnol. 2020, 50, 204-214. [CrossRef] [PubMed]

188. Busto, V.D.; Calabró-López, A.; Rodríguez-Talou, J.; Giulietti, A.M.; Merchuk, J.C. Anthraquinones production in Rubia tinctorum cell suspension cultures: Down scale of shear effects. Biochem. Eng. J. 2013, 77, 119-128. [CrossRef] 